\title{
The Natural Resource Curse: A Survey
}

\author{
Jeffrey Frankel \\ CID Working Paper No. 195 \\ May 2010
}
(C) Copyright 2010 Jeffrey Frankel and the President and Fellows of Harvard College

\section{Working Papers Center for International Development at Harvard University}


Dec. 11, 2009; revised May 16+ 2010.

\title{
The Natural Resource Curse: A Survey
}

\author{
Jeffrey Frankel \\ Harpel Professor of Capital Formation and Growth, Harvard University
}

This paper is a revised version of NBER Working Paper No. 15836. It was written for Export Perils, edited by Brenda Shaffer (forthcoming, University of Pennsylvania Press).

The author would like to thank the Azerbaijan Diplomatic Academy in Baku and the Weatherhead Center for International Affairs at Harvard University for support, and Rabah Arezki, Sebastian Bustos, Oyebola Olabisi, and Lant Pritchett for comments.

\begin{abstract}
It is striking how often countries with oil or other natural resource wealth have failed to grow more rapidly than those without. This is the phenomenon known as the Natural Resource Curse. The principle is not confined to individual anecdotes or case studies, but has been borne out in some econometric tests of the determinants of economic performance across a comprehensive sample of countries. This paper considers six aspects of commodity wealth, each of interest in its own right, but each also a channel that some have suggested could lead to sub-standard economic performance. They are: long-term trends in world commodity prices, volatility, permanent crowding out of manufacturing, poor institutions, unsustainability, and cyclical Dutch Disease.

Skeptics have questioned the Natural Resource Curse, pointing to examples of commodity-exporting countries that have done well and arguing that resource endowments and booms are not exogenous. Clearly, the relevant policy question for a country with natural resources is how to make the best of them. The paper concludes with a consideration of ideas for institutions that could help a country that is endowed with, for example, oil overcome the pitfalls of the Curse and achieve good economic performance. The most promising ideas include indexation of oil contracts, hedging of export proceeds, denomination of debt in terms of oil, Chile-style fiscal rules, a monetary target that emphasizes product prices, transparent commodity funds, and lump-sum distribution.
\end{abstract}

Keywords: commodities, Dutch Disease, energy, minerals, natural resources, nonrenewable, oil

JEL subject codes: O13, O1 , O, Q01 


\section{Outline}

Resource Curse: Introduction

I. Long-term trends in world commodity prices

a. The determination of the export price on world markets

b. The hypothesis of a declining trend: the old "structuralist school” (Prebisch-Singer)

c. Hypotheses of rising trends in non-renewable resource prices

i. Hotelling and the interest rate

ii. Malthusianism and the "peak oil" hypothesis

d. Evidence

i. Statistical time series studies

ii. Paul Ehrlich versus Julian Simon

II. Volatility of commodity prices

a. Low short-run elasticities

b. Costs of volatility

III. The Natural Resource Curse and possible channels

a. The statistical evidence on natural resources and economic performance

b. Institutions

i. Institutions and development

ii. Oil, institutions, and governance

c. Unsustainability and anarchy

i. Unenforceable natural resource property rights

ii. Do mineral riches lead to wars?

d. Oil and democracy

IV. The Dutch Disease and procyclicality

a. The Macroeconomics of the Dutch Disease

b. Procyclicality in developing countries

c. The procyclicality of capital flows

d. The procyclicality of fiscal policy

V. Institutions and policies to avoid the curse

a. Institutions that were supposed to stabilize but have not worked.
i. Marketing boards
ii. Taxation of commodity production
iii. Producer subsidies
iv. Other government stockpiles
v. Price controls for consumers
vi. OPEC and other International cartels

b. Devices to share risks

i. Price-setting in contracts with foreign companies

ii. Hedging in commodity futures markets

iii. Denomination of debt in terms of commodity prices

c. Monetary policy

i. Managed floating

ii. Alternative nominal anchors

d. Institutions to make national saving procyclical

i. Reserve accumulation by central banks

ii. Rules for the budget deficit. Example: Chile

iii. Sovereign Wealth Funds. Example: Sao Tome and Principe

iv. Lump sum distribution in booms. Example: Alaska

v. Reducing net private capital inflows during booms

e. External checks

VI. Summary 


\section{The Resource Curse: Introduction}

It has been observed for some decades that the possession of oil or other valuable mineral deposits or natural resources does not necessarily confer economic success. Many African countries such as Angola, Nigeria, Sudan, and the Congo are rich in oil, diamonds, or other minerals, and yet their peoples continue to experience low per capita income and low quality of life. Meanwhile, the East Asian economies Japan, Korea, Taiwan, Singapore and Hong Kong have achieved western-level standards of living despite being rocky islands (or peninsulas) with virtually no exportable natural resources. Auty $(1993,2001)$ is apparently the one who coined the phrase "natural resource curse" to describe this puzzling phenomenon. Its use spread rapidly.

Figure 1, reproduced from Manzano and Rigobon (2008), illustrates for a cross section of countries. Exports of primary products as a fraction of GDP appear on the horizontal axis and economic growth on the vertical axis. The relationship on average is slightly negative. The negative correlation is not very strong, masking almost as many resource successes as failures. But it certainly suggests no positive correlation between natural resource wealth and economic growth.

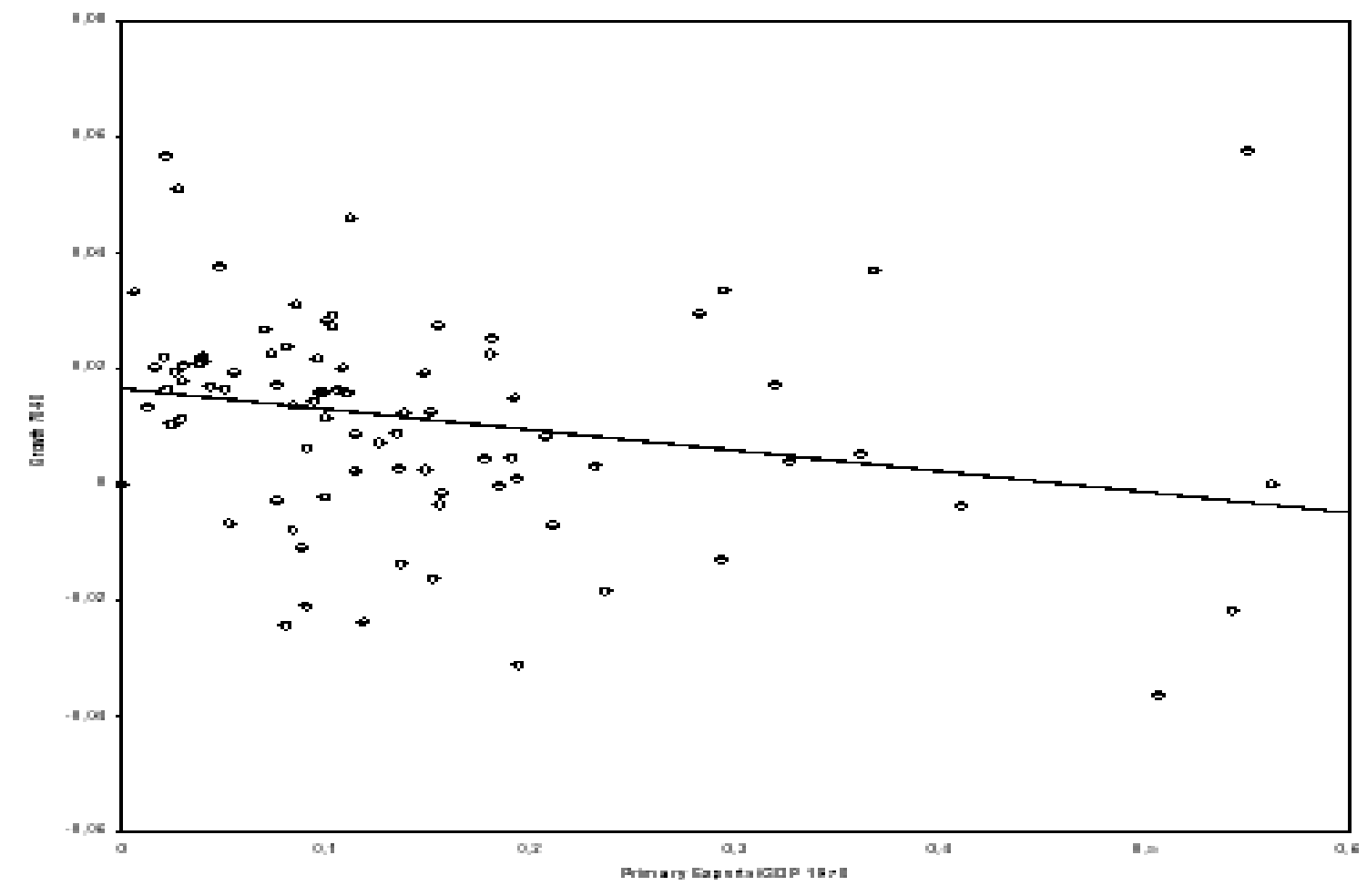

Figure 1: Natural Resource Abundance and Growth

Source: Manzano and Rigobon (2008)

How could abundance of hydrocarbon deposits, or other mineral and agricultural products, be a curse? What would be the mechanism for this counter-intuitive relationship? Broadly speaking, there are at least seven lines of argument. First, prices of such commodities could be subject to secular decline on world markets. Second, 
natural resources could be dead-end sectors in another sense: they may crowd out manufacturing, and the latter sector might be the one to offer dynamic benefits and spillovers that are good for growth. (It does not sound implausible that "industrialization" could be the essence of economic development.) Third, the volatility of world prices of energy and other mineral and agricultural commodities, which is known to be especially high, could be problematic. Fourth, countries where physical command of mineral deposits by the government or a hereditary elite automatically confers wealth on the holders may be less likely to develop the institutions, such as rule of law and decentralization of decision-making, that are conducive to economic development, as compared to countries where moderate taxation of a thriving market economy is the only way to finance the government. Fifth, when it is difficult to impose property rights on non-renewable resources, as under frontier conditions, they are likely to be depleted too fast, leaving the country with little to show for it. Sixth - countries that are endowed with natural resources could have a proclivity for armed conflict, which is inimical to economic growth. Seventh - swings in commodity prices could engender excessive macroeconomic instability, via the real exchange rate and government spending, imposing unnecessary costs. We consider each of these topics.

The conclusion will not be that mineral wealth need necessarily lead to inferior economic or political development, through any of these channels. Rather, it is best to view commodity abundance as a double-edged sword, with both benefits and dangers. It can be used for ill as easily as for good. ${ }^{1}$ That mineral wealth does not in itself confer good economic performance is a striking enough phenomenon, without exaggerating the negative effects. The priority for any country should be on identifying ways to sidestep the pitfalls that have afflicted other mineral producers in the past, and to find the path of success. The last section of the paper explores some of the institutional innovations that can help avoid the natural resource curse and achieve natural resource blessings instead.

\section{Long-term trends in world commodity prices}

\section{a. The determination of the export price on world markets}

Developing countries tend to be smaller economically than major industrialized countries, and more likely to specialize in the exports of basic commodities like oil. As a result, they are more likely to fit the small open economy model: they can be regarded as price-takers, not just for their import goods, but for their export goods as well. That is, the prices of their tradable goods are generally taken as given on world markets. The price-taking assumption requires three conditions: low monopoly power, low trade barriers, and intrinsic perfect substitutability in the commodity as between domestic and foreign producers - a condition usually met by primary products (and usually not met by manufactured goods and services). To be literal, not every barrel of oil is the same as every other and not all are traded in competitive markets. Furthermore, Saudi Arabia

Mikesell (1997), Stevens (2003); Lederman and Maloney (2008); Wright and Czelusta (2003, 2004, 2006); Luong and Weinthal (2010), 
does not satisfy the third condition, due to its large size in world oil markets. ${ }^{2}$ But the assumption that most oil producers are price-takers holds relatively well.

To a first approximation, then, the local price of oil is equal to the dollar price on world markets times the country's exchange rate. It follows, for example, that a devaluation should push up the price of oil quickly and in proportion (leaving aside preexisting contracts or export restrictions). An upward revaluation of the currency should push down the price of oil in proportion.

Throughout this paper we assume that the domestic country must take the price of the export commodity as given, in terms of foreign currency. We begin by considering the hypothesis that the given world price entails a long-term secular decline. The subsequent section of the paper considers the volatility in the given world price.

\section{b. The hypothesis of a declining trend in commodity prices (Prebisch- Singer)}

The hypothesis that the prices of mineral and agricultural products follow a downward trajectory in the long run, relative to the prices of manufactures and other products, is associated with Raul Prebisch (1950) and Hans Singer (1950), and what used to be called the "structuralist school." The theoretical reasoning was that world demand for primary products is inelastic with respect to world income. That is, for every one percent increase in income, the demand for raw materials increases by less than one percent. Engel's Law is the (older) proposition that households spend a lower fraction of their income on food and other basic necessities as they get richer.

This hypothesis, if true, would readily support the conclusion that specializing in natural resources was a bad deal. Mere "hewers of wood and drawers of water" would remain forever poor (Deuteronomy 29:11) if they did not industrialize. The policy implication that was drawn by Prebisch and the structuralists was that developing countries should discourage international trade with tariff and non-tariff barriers, to allow their domestic manufacturing sector to develop behind protective walls, rather than exploiting their traditional comparative advantage in natural resources as the classic theories of free trade would have it. This Import Substitution Industrialization” policy was adopted in most of Latin America and much of the rest of the developing world in the 1950s, 60s and 70s. The fashion reverted in subsequent decades, however.

\section{c. Hypotheses of rising trends in non-renewable resource prices (Malthus and Hotelling)}

There also exist persuasive theoretical arguments that we should expect prices of oil and other minerals to experience upward trends in the long run. The arguments begin with the assumption that we are talking about non-perishable non-renewable resources,

2 If OPEC functioned effectively as a true cartel, then it would possess even more monopoly power in the aggregate. We assume here, however, that OPEC does not currently exercise much monopoly power beyond that of Saudi Arabia, because so many non-members now produce oil and because even OPEC members usually do not feel constrained to stay within assigned quotas. 
i.e., deposits in the earth's crust that are fixed in total supply and are gradually being depleted. (The argument does not apply as well to agricultural products.)

Let us add one more assumption: whoever currently has claim to the resource - an oil company - can be confident that it will retain possession, unless it sells to someone else, who then has equally safe property rights. This assumption excludes cases where warlords compete over physical possession of the resource. It also excludes cases where private oil companies fear that their contracts might be abrogated or their possessions nationalized. $^{3}$ Under such exceptions, the current owner has a strong incentive to pump the oil or extract the minerals quickly, because it might never benefit from whatever is left in the ground. One explanation for the sharp rise in oil prices between 1973 and 1979, for example, is that private Western oil companies over the preceding two decades had anticipated the possibility that newly assertive developing countries would eventually nationalize the oil reserves within their borders, and thus had kept prices low by pumping oil more quickly than they would have done had they been confident that their claims would remain valid indefinitely.

\section{i. Hotelling and the interest rate}

Let us begin, at the risk of some oversimplification, by assuming also that the fixed deposits of oil in the earth's crust are all sufficiently accessible that the costs of exploration, development, and pumping are small compared to the value of the oil. Hotelling (1931) deduced from these assumptions the important theoretical principle that the price of oil in the long run should rise at a rate equal to the interest rate.

The logic is as follows. At every point in time the owner of the oil - whether a private oil company or state-owned -- chooses how much to pump and how much to leave in the ground. Whatever is pumped can be sold at today's price (this is the pricetaker assumption) and the proceeds invested in bank deposits or US Treasury bills which earn the current interest rate. If the value of the oil in the ground is not expected to increase in the future, or not expected to increase at a sufficiently rapid rate, then the owner has an incentive to extract more of it today, so that he earns interest on the proceeds. As oil companies worldwide react in this way, they drive down the price of oil today, below its perceived long-run level. When the current price is below its perceived long-run level, companies will expect that the price must rise in the future. Only when the expectation of future appreciation is sufficient to offset the interest rate will the oil market be in equilibrium. That is, only then will oil companies be close to indifferent between pumping at a faster rate and a slower rate.

To say that the oil prices are expected to increase at the interest rate means that it should do so on average; it does not mean that there won't be price fluctuations above and below the trend. But the theory does imply that, averaging out short-term unexpected fluctuations, oil prices in the long term should rise at the interest rate.

If there are constant costs of extraction and storage, then the trend in prices will be lower than the interest rate, by that amount; if there is a constant convenience yield

3 Bohn and Deacon (2000) show how insecure ownership rights inhibit investment in natural resources. The concern that insecure property rights leads to excessively rapid depletion is further explored in Section III.c. 
from holding inventories, then the trend in prices will be higher than the interest rate, by that amount. ${ }^{4}$

\section{ii. Malthusianism and the "peak oil” hypothesis}

The idea that natural resources are in fixed supply, and that as a result their prices must rise in the long run as reserves begin to run low, is much older than Hotelling. It goes back to Thomas Malthus (1798) and the genesis of fears of environmental scarcity (albeit without the role of the interest rate). Demand grows with population, supply is fixed; what could be clearer in economics than the prediction that price will rise? ${ }^{5}$

The complication is that supply is not fixed. True, at any point in time there is a certain stock of oil reserves that have been discovered. But the historical pattern has long been that, as that stock is depleted, new reserves are found. When the price goes up, it makes exploration and development profitable for deposits that are farther under the surface or are underwater or in other hard-to-reach locations. This is especially true as new technologies are developed for exploration and extraction.

Over the two centuries since Malthus, or the 70 years since Hotelling, exploration and new technologies have increased the supply of oil and other natural resources at a pace that has roughly counteracted the increase in demand from growth in population and incomes. ${ }^{6}$

Just because supply has always increased in the past does not necessarily mean that it will always do so in the future. In 1956 Marion King Hubbert, an oil engineer,

4 The same arbitrage condition that implies a positive long-run price trend also can explain a major source of shorter-run price swings. The real price of oil should be unusually high during periods when real interest rates are low (e.g., due to easy monetary policy), so that a poor expected future return to leaving the oil in the ground offsets the low interest rate. By contrast, when real interest rates are high (e.g., due to tight monetary policy), current oil prices should lie below their long-run equilibrium, because an expected future rate of price increase is needed in order to offset the high interest rate. Very low US real interest rates boosted commodity prices toward the end of the 1970s, especially in dollar terms, and high US real interest rates drove them down in the 1980s, again especially in dollar terms. In the years 2003-2010, low interest rates may again have been a source of high commodity prices. (References by the author include Frankel, 1986, 2008a,b; Frankel and Hardouvelis, 1985; Frankel and Rose, 2009; and "Real Interest Rates Cast a Shadow Over Oil," Financial Times, April 15, 2005. Also Barsky and Summers, 1988, Part III; and Caballero, Farhi and Gourinchas, 2008.) Barsky and Killian (2002) and Killian (2009) believe that many of the big oil price "shocks" have in reality been endogenous with respect to monetary policy. Some, of course, believe that destabilizing speculators are to blame for price swings.

${ }^{5}$ Even though Malthusianism predicts rising prices for commodities and structuralism predicts falling prices, both Malthus and Prebisch supported protection against imports. The resolution of the paradox is that Malthus had in mind England, where the import would be grain, while Prebisch had in mind Argentina, where grain would be the export and manufactures would be the import.

${ }^{6}$ Krautkraemer (1998) and Wright and Czelusta (2003, 2004, 2006). 
predicted that the flow supply of oil within the United States would peak in the late 1960s and then start to decline permanently. The prediction was based on a model in which the fraction of the country's reserves that has been discovered rises through time, and data on the rates of discovery versus consumption are used to estimate the parameters in the model. Unlike myriad other pessimistic forecasts, this one came true on schedule, earning subsequent fame for its author. The planet Earth is a much larger place than the United States, but it too is finite. A number of analysts have extrapolated Hubbert's words and modeling approach to claim that the same pattern would follow for extraction of the world's oil reserves. Specifically, some of them claim the 2000-2008 run-up in oil prices confirmed a predicted global "Hubbert's Peak.," It remains to be seen whether we are currently witnessing a peak in world oil production, notwithstanding that forecasts of such peaks have proven erroneous in the past.

\section{d. Evidence}

i. Statistical time series studies

With strong theoretical arguments on both sides, either for an upward trend or for a downward trend, one must say that it is an empirical question. Although specifics will vary depending on individual measures, it is possible to generalize somewhat across commodity prices. ${ }^{8}$ Terms of trade for commodity producers had a slight upward trend from 1870 to World War I, a downward trend in the inter-war period, upward in the 1970s, downward in the 1980s and 1990s, and upward in the first decade of the 21st century.

What is the overall statistical trend in the long run? Some authors find a slight upward trend, some a slight downward trend. ${ }^{9}$ The answer seems to depend, more than anything else, on the date of the end of the sample. Studies written after the commodity price increases of the 1970s found an upward trend, but those written after the 1980s found a downward trend, even when both kinds of studies went back to the early $20^{\text {th }}$ century. No doubt, when studies using data through 2008 are completed some will again find a positive long run trend. This phenomenon is less surprising than it sounds. When a real price undergoes large ten-year cycles around a trend, estimates of the trend are very sensitive to the precise time period studied. ${ }^{10}$

ii. The wager of Paul Ehrlich against Julian Simon

${ }^{7}$ E.g., Deffeyes (2005).

${ }^{8}$ Although prices do not always move together for oil, other minerals, and agricultural products, there is a surprisingly high correlation. Pindyck and Rotemberg (1990).

${ }_{9}^{9}$ Cuddington (1992), Cuddington, Ludema and Jayasuriya (2007), Cuddington and Urzua (1989), Grilli and Yang (1988), Pindyck (1999), Hadass and Williamson (2003), Reinhart and Wickham (1994), Kellard and Wohar (2005), Balagtas and Holt (2009) and Harvey, Kellard, Madsen and Wohar (2010).

${ }^{10}$ The same phenomenon is evident in real exchange rates, stock prices, and housing prices. 
Paul Ehrlich is a biologist, highly respected among scientists but with a history of sensationalist doomsday predictions regarding population, the environment, and resource scarcity. Julian Simon was a libertarian economist, frustrated by the failure of the public to hold Malthusians like Ehrlich accountable for the poor track record of their predictions. In 1980, Simon publicly bet Ehrlich $\$ 1000$ that the prices of five minerals would decline between then and 1990. (Simon let Ehrlich choose the 10-year span and the list of minerals: copper, tin, nickel, chromium and tungsten.) Ehrlich's logic was Malthusian: because supplies were fixed while growth of populations and economies would raise demand, the resulting scarcity would continue to drive up prices. He, like most observers, was undoubtedly mentally extrapolating into the indefinite future what had been a strong upward movement in commodity prices over the preceding decade. Simon's logic, on the other hand, is called cornucopian. Yes, the future would repeat the past. The relevant pattern from the past was not the ten-year trend, however, but rather a century of cycles: resource scarcity does indeed drive up prices, whereupon, supply, demand and, especially, technology respond with a lag, driving the prices back down. Simon was precisely right. He won the bet handily: not only did the real price of the basket of five minerals decline over the subsequent ten years, but every one of the five real prices also declined. He was also, almost certainly, right about the reasons: in response to the high prices of 1980, new technologies came into use, buyers economized, and new producers entered the market.

The Ehrlic-versus-Simon bet carries fascinating implications, not just for Malthusians versus Cornucopians, environmentalists versus economists, extrapolationists versus contrarians, and futurologists versus historians. For present purposes, the main important point is slightly more limited. Simple extrapolation of medium-term trends is foolish. One must take a longer-term perspective. The review of the statistical literature in the preceding sub-section illustrated the importance of examining as long a statistical time series as possible.

However, one should seek to avoid falling prey to either of two reductionist arguments at the philosophical poles of Mathusianism and cornucopianism. On the one hand, the fact that the supply of minerals in the earth's crust is a finite number, does not in itself justify the apocalyptic conclusion that we must necessarily run out. As Sheik Ahmed Zaki Yamani, the former Saudi oil minister, famously said, "The Stone Age came to an end not for a lack of stones and the oil age will end, but not for a lack of oil." Malthusians do not pay enough attention to the tendency for technological progress to ride to the rescue. On the other hand, the fact that the Malthusian forecast has repeatedly been proven false in the past does not in itself imply the Panglossian forecast that this will always happen in the future. ${ }^{11}$ One must seek, rather, a broad perspective in which all relevant reasoning and evidence are brought to bear in the balance.

\footnotetext{
${ }^{11}$ In the last decade alone, black swan thinking of this sort ("because I have never personally observed this happen in the past, it won't happen in the future") led Americans to both the national security tragedy that began on September 11, 2001, and the financial crisis that began in the summer of 2007. Only small minorities of experts, those who had a truly broad perspective, were able to recognize ahead of time the possibilities of a
} 


\section{Medium-term Volatility of Commodity Prices}

Of course the price of oil does not follow a smooth path, whether upward or downward. Rather it experiences large short- and medium-term swings around a longerterm average. The world market prices for oil and natural gas are more volatile than those for any other mineral and agricultural commodities. (Copper and coffee are two runner-ups.) Even other mineral and agricultural commodity prices are far more volatile than prices of most manufactured products or services.

Some have suggested that it is precisely the volatility of natural resource prices, rather than the trend, that is bad for economic growth. ${ }^{12}$

\section{a. Low short-run elasticities}

It is not hard to understand why the market price of oil is volatile in the short run, or even the medium run. Because elasticities of supply and demand with respect to price are low, relatively small fluctuations in demand (due, for example, to weather) or in supply (due, for example, to disruptions) require a large change in price to re-equilibrate supply and demand. Demand elasticities are low in the short run largely because the capital stock at any point in time is designed physically to operate with a particular ratio of energy to output. Supply elasticities are also often low in the short run because it takes time to adjust output. Inventories can cushion the short run impact of fluctuations, but they are limited in size. There is a bit of scope to substitute across different fuels, even in the short run. But this just means that the prices of oil, natural gas, and other fuels tend to experience their big medium-term swings together.

In the longer run, elasticities are far higher, both on the demand side and the supply side. This dynamic was clearly at work in the oil price shocks of the 1970s - the quadrupling after the Arab oil embargo of 1973 and the doubling after the Iranian revolution of 1979, which elicited relatively little consumer conservation or new supply sources in the short run, but a lot of both after a few years had passed. People started insulating their houses and driving more fuel-efficient cars, and oil deposits were discovered and developed in new countries. This is a major reason why the real price of oil came back down in the 1980s and 1990s.

In the medium term, oil may be subject to a cob-web cycle, due to the lags in response: The initial market equilibrium is a high price; the high price cuts demand after some years, which in turn leads to a new low price, which raises demand with a lag, and so on. In theory, if people have rational expectations, they should look ahead to the next price cycle before making long-term investments in housing or drilling. But the

mass terrorist attack and a plunge in housing prices even though neither had happened in living American memory.

${ }^{12}$ Blattman, Hwang, and Williamson (2007), Hausmann and Rigobon (2003) and Poelhekke and van der Ploeg (2007). 
complete sequence of boom-bust-boom over the last 35 years looks suspiciously like a cobweb cycle nonetheless.

\section{b. Is volatility per se detrimental to economic performance?}

Gamblers aside, most people would rather have less economic volatility than more. But is variability necessarily harmful for long run growth? Some studies and historical examples suggest that high volatility can accompany the rapid growth phase of a country's development (the United States before World War I).

Cyclical shifts of movable resources (labor and land) back and forth across sectors - mineral, agricultural, manufacturing, services - may incur needless transaction costs. Frictional unemployment of labor, incomplete utilization of the capital stock, and incomplete occupancy of housing are true deadweight costs, even if they are temporary. Government policy-makers may not be better than individual economic agents at discerning whether a boom in the price for the export commodity is temporary or permanent. But the government cannot completely ignore the issue of volatility, under the logic that the private market can deal with it. When it comes to exchange rate policy or fiscal policy, governments must necessarily make judgments about the likely permanence of shocks. Moreover, since commodities are inherently risky, a diversified country may indeed be better off than one specialized in oil or a few other commodities, other things equal. On the other hand, the private sector dislikes risk as much as the government does, and will take steps to mitigate it; thus one must think where the market failure lies before assuming that a policy of deliberate diversification is necessarily justified.

In Part IV of the paper we will consider the implications of the medium-term boom-bust cycle further, under the heading of the Dutch Disease, and how to deal with short-term volatility further, under the heading of policy responses.

\section{Possible Channels for the Natural Resource Curse}

The Natural Resource Curse is not confined to individual anecdotes or case studies, but has been borne out in some statistical tests of the determinants of economic performance across a comprehensive sample of countries. Sachs and Warner (1995) kicked off the econometric literature, finding that economic dependence on oil and mineral is correlated with slow economic growth, controlling for other structural attributes of the country. Sachs and Warner (2001) summarized and extended previous research showing evidence that countries with great natural resource wealth tend to grow more slowly than resource-poor countries. They say their result is not easily explained by other variables, or by alternative ways to measure resource abundance. Their paper claims that there is little direct evidence that omitted geographical or climate variables explain the curse, or that there is a bias in their estimates resulting from some other unobserved growth deterrent. Other studies that find a negative effect of oil, in particular, on economic performance, include Kaldor, Karl and Said (2007); Ross (2001); Sala-i-Martin and Subramanian (2003); and Smith (2004). 
The result is by no means universal, especially when one generalizes beyond oil. Norway is conspicuous as an oil-producer that is at the top of the international league tables for governance and economic performance. ${ }^{13}$ As many have pointed out, Botswana and the Congo are both abundant in diamonds; yet Botswana is the best performer in continental Africa in terms of democracy, stability, and rapid growth of income, ${ }^{14}$ while the Congo is among the very worst. ${ }^{15}$

Among the statistical studies, Delacroix (1977), Davis (1995), and Herb (2005) all find no evidence of the natural resource curse. Most recently, Alexeev and Conrad (2009) find that oil wealth and mineral wealth have positive effects on income per capita, when controlling for a number of variables, particularly dummies for East Asia and Latin America. In some cases, especially if the data do not go back to a time before oil was discovered, the reason different studies come to different results is that oil wealth may raise the level of per capita income, while reducing or failing to raise the growth rate of income (or the end-of-sample level of income, if the equation conditions on initial income). ${ }^{16}$

In some cases the crucial difference is whether "natural resource intensity" is measured by true endowments ("natural resource wealth"), or rather by exports ("natural resource dependence”). The skeptics argue that commodity exports are highly endogenous, in several different ways. ${ }^{17}$

On the one hand, basic trade theory readily predicts that a country may show a high mineral share in exports, not necessarily because it has a higher endowment of minerals than other countries (absolute advantage) but because it does not have the ability to export manufactures (comparative advantage). This is important because it offers an explanation for negative statistical correlations between mineral exports and economic development, an explanation that would invalidate the common inference that minerals are bad for growth.

${ }^{13}$ Røed Larsen (2004). Norway is literally ranked number one out of 182 countries in the Human Development Index. Kuwait, Qatar, and the UAE are also in the top fifth on the list. In terms of real income, Norway is ranked number 5, just behind Qatar and the UAE. For comparison, the US is number 9 in real income, and 13 on the HDI.

14 Engelbert (2000), Sarraf and Jimanji (2001), Acemoglu, Johnson, and Robinson (2003) and Iimi (2006) are among those noting Botswana's conspicuous escape from the Resource Curse of its neighbors.

15 Most African countries grew more strongly in the years 2000-08 than previously, in part due to rising mineral prices (Beny and Cook, 2009). But countries like the Congo, Chad and Sierra Leone remain in the bottom 5 per cent of countries in the Human Development Index. Oil-rich Nigeria ranks $159^{\text {th }}$ out of 182. (Human Development Report, 2009. The figures pertain to 2007.)

16 See Rodriguez and Sachs (1999) and Alexeev and Conrad (2009).

${ }^{17}$ Maloney (2002) and Wright and Czelusta (2003, 2004, 2006). Even recorded reserves, the most common measure of endowments, are somewhat endogenous as well, since they reflect discoveries, which in turn reflect both world prices and the productivity of the exploration industry, global and local. 
On the other hand, the skeptics also have plenty of examples where successful institutions and industrialization went hand in hand with rapid development of mineral resources. Economic historians have long noted that coal deposits and access to iron ore deposits (two key inputs into steel production) were geographic blessings that helped start the industrial revolutions in England, the vicinity of the lower Rhine, and the American Great Lakes region. Subsequent cases of countries that were able to develop efficiently their resource endowments as part of strong economy-wide growth include: the United States during its pre-war industrialization period ${ }^{18}$, Venezuela from the 1920 s to the 1970s, Australia since the 1960s, Norway since its oil discoveries of 1969, Chile since adoption of a new mining code in 1983, Peru since a privatization program in 1992, and Brazil since the lifting of restrictions on foreign mining participation in $1995 .{ }^{19}$

Examples of countries that were equally well-endowed geologically but that failed to develop their natural resources efficiently include Chile and Australia before World War I and Venezuela since the 1980s. ${ }^{20}$

It is not that countries with oil wealth will necessarily achieve worse performance than those without. Few would advise a country with oil or other natural resources that it would be better off destroying them or refraining from developing them. Oil-rich countries can succeed. The question is how to make best use of the resource. The goal is to achieve the prosperous record of a Norway rather than the disappointments of Nigeria. The same point applies to other precious minerals: the goal is to be a Botswana rather than a Bolivia, a Chile rather than a Congo.

Let us return to a consideration of various channels whereby oil wealth could lead to poor performance. Based on the statistical evidence, we have already largely rejected the hypothesis of a long-term negative trend in world prices, while accepting the hypothesis of high volatility. But we have yet to spell out exactly how high price volatility might lead to slower economic growth. In addition we have yet to consider in detail the hypotheses according to which oil wealth leads to poor institutions - including military conflict and authoritarianism - which in turn might lead to poor economic performance.

\section{a. Is commodity specialization per se detrimental to growth?}

What are the possible negative externalities to specialization in natural resources, beyond volatility? What are the positive externalities to diversification into manufacturing?

Outside of classical economics, diversification out of primary commodities into manufacturing in most circles is considered self-evidently desirable. Several false

18 David and Wright (1997).

19 Wright and Czelusta (2003, pp. 4-7, 12-13, 18-22).

20 Hausmann (2003, p.246): “Venezuela's growth collapse took place after 60 years of expansion, fueled by oil. If oil explains slow growth, what explains the previous fast growth?” 
arguments have been made for it. One is the Prebisch-Singer hypothesis of secularly declining commodity prices, which we judged to lack merit in Part I of this paper. Another is the mistaken "cargo cult" inference -- based on the observation that advanced countries have heavy industries like steel mills -- that these visible monuments are necessarily the route to economic development. But one should not dismiss more valid considerations, just because less valid arguments for diversification into manufacturing are sometimes made.

Is industrialization the sine qua non of economic development? Is encouragement of manufacturing necessary to achieve high income? Classical economic theory says "no:" countries are best off producing whatever is their comparative advantage, whether that is natural resources or manufacturing. In this $19^{\text {th }}$ century view, attempts by Brazil to industrialize were as foolish as it would have been for Great Britain to try to grow coffee and oranges in hothouses. But the "structuralists" mentioned early in this chapter were never alone in their feeling that countries only get sustainably rich if they industrialize, oil-rich sheikdoms notwithstanding. Nor were they ever alone in feeling that industrialization in turn requires an extra push from the government (at least for latecomers), often known as industrial policy.

Matsuyama (1992) provided an influential model formalizing this intuition: the manufacturing sector is assumed to be characterized by learning by doing, while the primary sector (agriculture, in his paper) is not. The implication is that deliberate policyinduced diversification out of primary products into manufacturing is justified, and that a permanent commodity boom that crowds out manufacturing can indeed be harmful. Hausmann, Klinger and Lopez-Calix (2009) explain how they think Algeria should go about diversifying its exports out of oil, not only in anticipation of exhaustion of oil reserves, but also because identifying the right directions to move within the "product space” will enhance long-term growth.

On the other side, it must be pointed out that there is no reason why learning by doing should be the exclusive preserve of manufacturing tradables. Nontradables can enjoy learning by doing. ${ }^{21}$ Mineral and agricultural sectors can as well. Some countries have experienced tremendous productivity growth in the oil, mineral, and agricultural sectors. American productivity gains have been aided by American public investment, since the late $19^{\text {th }}$ century, in such knowledge infrastructure institutions as the U.S. Geological Survey, the Columbia School of Mines, the Agricultural Extension program, and Land-Grant Colleges. Although well-functioning governments can play a useful role in supplying these public goods for the natural resource sector, this is different than mandating government ownership of the resources themselves. In Latin America, for example, public monopoly ownership and prohibition on importing foreign expertise or capital has often stunted development of the mineral sector, whereas privatization has set it free. $^{22}$ Moreover, attempts by governments to force linkages between the mineral sector and processing industries have not always worked. ${ }^{23}$

21 Torvik (2001).

22 Wright and Czelusta (2003, p.6, 25; 18-21).

23 Hausmann, Klinger and Lawrence (2008) warn of the pitfalls of assuming that South Africa, for example, can move from diamond mining to diamond cutting. They are not 


\section{b. Institutions}

i. Institutions and development

A prominent trend in thinking regarding economic development is that the quality of institutions is the deep fundamental factor that determines which countries experience good performance and which do not, ${ }^{24}$ and that it is futile to recommend good macroeconomic or microeconomic policies if the institutional structure is not there to support them. Rodrik, Subramanian, and Trebbi (2003) use as their measure of institutional quality an indicator of the rule of law and protection of property rights (taken from Kaufmann, Kraay and Zoido-Lobaton, 2002). Acemoglu, Johnson, and Robinson (2001) use a measure of expropriation risk to investors. Acemoglu, Johnson, Robinson, and Thaicharoen (2003) measure the quality of a country's "cluster of institutions" by the extent of constraints on the executive. The theory is that weak institutions lead to inequality, intermittent dictatorship, and lack of any constraints to prevent elites and politicians from plundering the country.

Institutions can be endogenous: the result of economic growth rather than the cause. (The same problem is encountered with other proposed fundamental determinants of growth, such as openness to trade and freedom from tropical diseases such as malaria.) Many institutions -- such as the structure of financial markets, mechanisms of income redistribution and social safety nets, tax systems, and intellectual property rules -- tend to evolve endogenously, in response to the level of income.

Econometricians address the problem of endogeneity by means of the technique of instrumental variables. What is a good instrumental variable for institutions, an exogenous determinant? Acemoglu, Johnson, and Robinson (2001) and Acemoglu, Johnson, Robinson, and Thaicharoen (2002) introduce the mortality rates of colonial settlers. The theory is that, out of all the lands that Europeans colonized, only those where Europeans actually settled were given good European institutions. Acemoglu et al chose their instrument on the reasoning that initial settler mortality rates determined whether Europeans subsequently settled in large numbers. ${ }^{25}$ One can help justify this otherwise idiosyncratic-sounding instrumental variable by pointing out that there need not be a strong correlation between the diseases that killed settlers and the diseases that afflict natives, and that both are independent of the countries' geographical suitability for trade. The conclusion of Rodrik et al is that institutions trump everything else -- the effects of both tropical geography and trade pale in the blinding light of institutions.

opposed to industrial policy, but rather believe that linkages are more likely where factor intensities and technological requirements are similar across sectors, rather than to upstream or downstream industries.

${ }^{24}$ Barro (1991) and North (1994).

${ }^{25}$ Glaeser, et al, (2004) argue against the settler variable. Hall and Jones (1999) consider latitude and the speaking of English or other Western European languages as proxies for European institutions. They don't distinguish an independent effect of tropical conditions. 
This is essentially the same result as found by Acemoglu et al (2002), Easterly and Levine (2002) and Hall and Jones (1999): institutions drives out the effect of policies, and geography matters primarily as a determinant of institutions. ${ }^{26}$ But it does not matter much whether the effect of institutions is merely one of several important deep factors or if, as these papers seem claim, it is the only important deep factor: clearly, institutions are important. ${ }^{27}$

\section{ii. Oil, institutions and governance}

Of the various possible channels through which natural resources could be a curse to long-run development, the quality of institutions and governance is perhaps the most widely hypothesized. Hodler (2006) and Caselli (2006) are among those finding a natural resource curse via internal struggle for ownership. Leite and Weidmann (1999) find that natural resource dependence has a substantial statistical effect on measures of corruption in particular. Gylfason and Zoega (2002) and Nankani (1979) find a negative effect via inequality. Gylfason (2001b) reviews a number of possible channels that could explain natural resource dependence, as measured by labor allocation, leading to worse average performance. ${ }^{28}$

It is not necessarily obvious, a priori, that endowments of oil should lead to inequality or authoritarianism or bad institutions generally. Humphreys, Sachs and Stiglitz (2007, p.2) point out that a government wishing to reduce inequality should in theory have an easier time of it in a country where much wealth comes from a nonrenewable resource in fixed supply, because taxing it runs less risk of eliciting a fall in output. This is in comparison to the more elastic supplies of manufactures and other goods or services, including agricultural goods, which are produced with a higher labor component. But the usual interpretation is that most governments in resource-rich countries have historically not been interested in promoting equality.

The "rent cycling theory" as enunciated by Auty (1990, 2001, 2007, 2009) holds that economic growth requires recycling rents via markets rather than via patronage. In high-rent countries the natural resource elicits a political contest to capture ownership, whereas in low-rent countries the government must motivate people to create wealth, for example by pursuing comparative advantage, promoting equality, and fostering civil society.

This theory is related to the explanation of economic historians Engerman and Sokoloff $(1997,2000,2002)$ as to why industrialization first took place in North America

${ }^{26}$ Easterly and Levine (2002) just group openness together with other policies.

${ }^{27}$ The imprecision of the word "institutions" can be frustrating (Frankel, 2003b). Good institutions are not necessarily equated with democracy. Central bank independence is an example where the two conflict. In the last section of this paper we consider examples of specific institutions that might lessen the Dutch Disease or Natural Resource Curse. ${ }^{28}$ Gylfason (2001a) finds a negative effect on growth via education and Gylfason and Zoega (2006) via crowding out investment. Gylfason (2000) finds a resource curse at work in Eastern Europe and Central Asia, through rent-seeking and policy failures. 
and not Latin America (and why in the Northeastern United States rather than the South). Lands endowed with extractive industries and plantation crops (mining, sugar, cotton) developed institutions of slavery, inequality, dictatorship, and state control, whereas those climates suited to fishing and small farms (fruits and vegetables, grain and livestock) developed institutions based on individualism, democracy, egalitarianism, and capitalism. When the industrial revolution came along, the latter areas were well-suited to make the most of it. Those that had specialized in extractive industries were not, because society had come to depend on class structure and authoritarianism, rather than on individual incentive and decentralized decision-making. The theory is thought to fit Middle Eastern oil exporters especially well. ${ }^{29}$

Isham, et al, (2005) find that the commodities that are damaging to institutional development, which they call "point source" resources, are, in addition to oil: other minerals, plantation crops, and coffee and cocoa (versus the same small-scale farm products identified by Engerman and Sokoloff). Sala-I-Martin and Subramanian (2003) and Bulte, Damania, and Deacon (2005) also find that point-source resources such as oil and some particular minerals undermine institutional quality and thereby growth, but not agricultural resources. Mehlum, Moene, and Torvik (2006) observe the distinction by designating them "lootable" resources. Arezki and Brückner (2009) find that oil rents worsen corruption (but, unusually, that they also improve civil liberties).

Some have questioned the assumption that oil discoveries are exogenous and institutions endogenous. In other words oil wealth is not necessarily the cause and institutions the effect, rather than the other way around. Norman (2009) points out that the discovery and development of oil is not purely exogenous, but rather is endogenous with respect to, among other things, the efficiency of the economy. Mehlum, Moene, and Torvik (2006), Robinson, Torvik and Verdier (2006), McSherry (2006), Smith (2007) and Collier and Goderis (2007) all argue that the important question is whether the country already has good institutions at the time that oil is discovered, in which case it is more likely to be put to use for the national welfare instead of the welfare of an elite. Alexeev and Conrad (2009) find no evidence that oil or mineral wealth interacts positively with institutional quality. ${ }^{30}$ But Arezki and Van der Ploeg (2007) use instrumental variables to control for the endogeneity of institutional quality and trade; they confirm that the adverse effect of natural resources on growth is associated with exogenously poor institutions and, especially, that it is associated with exogenously low levels of trade. Luong and Weinthal (2010), in a study of the five former Soviet republics that have oil and similar initial conditions, conclude that the choice of ownership

${ }^{29}$ E.g., Iran. Mahdavi (1970), Skocpol (1982, p. 269), and Smith (2007).

${ }^{30}$ Before the interactive effects, they report significant negative effects of oil or mineral wealth on institutional quality when conditioning on actual initial income, but these effects disappear in their preferred equation, which does not condition on initial income. Institutional quality is measured by a standard rule of law index from the World Bank (and is instrumented by such variables as absolute latitude and fraction of the population speaking English or other major Western European languages). 
structure makes the difference as to whether oil turns out to be a blessing rather than a curse. ${ }^{31}$

\section{c. Unsustainability and anarchy}

What happens when a depletable natural resources is indeed depleted? This question is not only of concern to environmentalists. It is also one motivation for the strategy of diversifying the economy out of natural resources into other sectors. The question is also a motivation for the "Hartwick rule," which says that all rents from exhaustible natural resources should be invested in reproducible capital, so that future generations do not suffer a diminution in total wealth (natural resource plus reproducible capital) and therefore in the flow of consumption. ${ }^{32}$

Each of these problems would be much less severe if a full assignment of property rights were possible, thereby giving the owners adequate incentive to conserve the resource in question. But often this is not possible, either physically or politically. The difficulty in enforcing property rights over some non-renewable resources constitutes a category of natural resource curse of its own.

\section{i. Unenforceable property rights over depletable resources}

While one theory holds that the physical possession of point-source mineral wealth undermines the motivation for the government to establish a broad-based regime of property rights for the rest of the economy, another theory holds that some natural resources do not lend themselves to property rights whether the government wants to apply them or not. Overfishing, overgrazing, and over-use of water are classic examples of the so-called "tragedy of the commons" that applies to "open access" resources. Individual fisherman or ranchers or farmers have no incentive to restrain themselves, even while the fisheries or pastureland or water aquifers are being collectively depleted. The difficulty in imposing property rights is particularly severe when the resource is dispersed over a wide area, as timberland. But even the classic point-source resource, oil, can suffer the problem, especially when wells drilled from different plots of land hit the same underground deposit.

This unenforceability of property rights is the market failure that can invalidate some of the standard neoclassical economic theorems in the case of open access resources. One obvious implication of unenforceability is that the resource will be depleted more rapidly than the optimization of the Hotelling calculation calls for. ${ }^{33}$ The benefits of free trade are another possible casualty: the country might be better off without the ability to export the resource, if doing so exacerbates the excess rate of

31 Their conclusion that private domestic ownership works best sounds convincing, until their data point in favor of this ownership structure turns out to be Russia. The alternatives are private foreign ownership (Kazakstan), state ownership and control (Turkmenistan and Uzbekistan), and state ownership with foreign participation (Azerbaijan).

32 Hartwick (1977) and Solow (1986).

33 E.g., Dasgupta and Heal (1985). 
exploitation. $^{34}$

Enforcement of property rights is all the more difficult in a frontier situation. The phrase "Wild West" captures the American experience, including legendary claimjumping in the gold or silver rushes of the late $19^{\text {th }}$ century and early 20th. Typically, only when a large enough number of incumbents has enough value at stake are the transactions costs of establishing a system of property rights overcome. ${ }^{35}$ Frontier rushes went on in many other parts of the world during this period as well. ${ }^{36}$ Today, anarchic conditions can apply in the tropical forest frontiers of the Amazon, Borneo or the Congo. ${ }^{37}$ Barbier (2005ab, 2007) argues that frontier exploitation of natural resources can lead to unsustainable development characterized by a boom-bust cycle as well as permanently lower levels of income in the long term.

\section{ii. Do mineral riches lead to wars?}

Domestic conflict is certainly bad for economic development, especially when violent. Where a valuable resource such as oil or diamonds is there for the taking, rather than requiring substantial inputs of labor and capital investment, factions are more likely to fight over it. Fearon and Laitin (2003), Collier and Hoeffler (2004), Humphreys (2005) and Collier (2007, Chapter 2) all find that economic dependence on oil and mineral wealth is correlated with civil war. Chronic conflict in such oil-rich countries as Angola and Sudan comes to mind. Civil war is, in turn, very bad for economic development.

The conclusion is not unanimous: Brunnschweiler and Bulte (2009) argue that the conventional measure of resource dependence is endogenous with respect to conflict, and that instrumenting for dependence eliminates its significance in conflict regressions. They find conflict increases dependence on resource extraction, rather than the other way around.

\section{d. Oil and Democracy}

Mahdavy (1970) was apparently the first to suggest — followed by Luciani (1987), Vandewalle (1998) and many others -- that Middle Eastern governments' access to rents, in the form of oil revenue, may have freed them from the need for taxation of their peoples, and that this in turn freed them from the need for democracy. The need for tax revenue is believed to require democracy under the theory "no taxation without

34 Brander and Taylor (1997).

35 Libecap (1974, 1989). He emphasizes the superiority of locally-grown rules for property rights over federally-imposed regimes. Another conclusion is that the establishment of property rights is much easier for mining than for common pool resources such as fisheries or (less obviously) crude oil.

36 Findlay and Lundahl $(1994,2001)$ study economic development in frontier countries of the late $19^{\text {th }}$ and early $20^{\text {th }}$ centuries.

37 Alston, Libecap and Schneider (1996) study the coming of land title to agriculture on the Brazilian frontier. 
representation.” Huntington (1991) generalized the principle beyond Middle Eastern oil producers to states with natural resources in other parts of the developing world.

Statistical studies across large cross-sections of countries followed. Ross (2001) finds that economic dependence on oil and mineral is correlated with authoritarian government. So do Barro (2000), Wantchekon (2002), Jenson and Wantchekon (2004), and Ross (2006). Smith (2004, 2007), Ulfelder (2007) and others generally find that authoritarian regimes have lasted longer in countries with oil wealth.

But Karl (1997) points out that Venezuela had already been authoritarian when oil was developed, and in fact transitioned to democracy at the height of its oil wealth. None of the Central Asian states are democracies, even though Kazakhstan is the only one of them with major oil production. Thus inspired, Haber and Menaldo (2009) look at historical time series data for a link to democracy from the share of oil or minerals in the economy and fail to find the statistically significant evidence that is typical of crosssection and panel studies. ${ }^{38}$ Similarly, Noland (2008) finds that oil rents are not a robust factor behind lack of democracy in Middle Eastern countries. When Dunning (2008) introduces fixed effects to take into account country-specific differences within Latin America, he finds that the negative correlation between oil profits and democracy reversese.

The question whether oil dependence tends to retard democracy should probably not be regarded as a component of the causal relation between oil and economic performance. Some correlates of democracy - rule of law, political stability, openness to international trade, initial equality of economic endowments and opportunities - do tend to be good for economic growth. But each of these other variables can also exist without democracy. Examples include pre-democratic Asian economies such as Korea or Taiwan. Some believe that Lee Kwan Yew in Singapore and Augusto Pinochet in Chile could not have achieved their economic reforms without authoritarian powers (the one certainly more moderate and benevolent than the other). On a bigger scale, it is said that China has grown so much faster than Russia since 1990 because Deng Xiao Peng chose to pursue economic reform before political reform while Michel Gorbachev did it the other way around. The statistical evidence is at best mixed as to whether democracy per se is good for economic performance. Barro (1996) finds that it is the rule of law, free markets, education, and small government consumption that are good for growth, not democracy per se. Tavares and Wacziarg (2001) find that it is education, not democracy per se. Alesina, et al, (1996) find that it is political stability. ${ }^{39}$ Some even find that, after controlling for important factors such as the rule of law and political stability, democracy has if anything a weak negative effect on growth.One can claim good evidence for the reverse causation, that economic growth leads to democracy, often assisted by the

\footnotetext{
${ }^{38}$ Loss of statistical power in pure cointegration time series tests might account for this. ${ }^{39}$ Bhattacharyya and Hodler (2009) find that natural resource rents lead to corruption, but only in the absence of high-quality democratic institutions. Collier and Hoeffler (2009) find that when developing countries have democracies, as opposed to advanced countries, they tend to feature weak checks and balances; as a result, when developing countries also have high natural resource rents the result is bad for economic growth.
} 
creation of a middle class, much more reliably than the other way around. ${ }^{40}$ Examples include Korea and Taiwan.Of course democracy is normally regarded as an end in itself, aside from whether it promotes economic growth. Even here, one must note that the benefits of the formalities of elections can be over-emphasized. For one thing, elections can be a sham. Such leaders as Robert Mugabe, Hamid Karzai, and George W. Bush have each claimed to have been elected without having in fact earned a majority of their public's votes. Western style or one-man one-vote elections should probably receive less priority in developing countries than the fundamental principles of rule of law, human rights, freedom of expression, economic freedom, minority rights, and some form of popular representation. ${ }^{41}$

\section{The Dutch Disease and Procyclicality}

The Dutch Disease refers to some possibly unpleasant side effects of a boom in oil or other mineral and agricultural commodities. ${ }^{42}$

\section{a. The Macroeconomics of the Dutch Disease}

The phenomenon arises when a strong, but perhaps temporary, upward swing in the world price of the export commodity causes:

- a large real appreciation in the currency (taking the form of nominal currency appreciation if the country has a floating exchange rate or the form of money inflows and inflation if the country has a fixed exchange rate ${ }^{43}$ );

- an increase in spending (especially by the government, which increases spending in response to the increased availability of tax receipts or royalties -discussed below);

- an increase in the price of nontraded goods (goods and services such as housing that are not internationally traded), relative to traded goods (manufactures and other internationally traded goods other than the export commodity),

\footnotetext{
${ }^{40}$ Helliwell (1994), Huber, Rueschemeyer and Stephens (1993), Lipset (1994) and Minier (1998).

41 Zakaria (1997, 2004).

${ }^{42}$ Gregory (1976), Corden (1984) and Neary and van Wijnbergen (1986) gave us three of the first models. The name Dutch Disease -- due to the Economist magazine -- was originally inspired by side-effects of natural gas discoveries by the Netherlands in the late 1950s; Kremers (1986).

43 E.g., Edwards (1986). During the boom of 2001-2008, examples of fixed-rate oilproducing countries where the real appreciation came via money inflows and inflation include Saudi Arabia and the Gulf emirates. Examples of floating-rate natural resource countries where the real appreciation took the form of nominal currency appreciation include Australia, Chile, Kazakhstan, Mexico, Norway, Russia, or South Africa. (Chen and Rogoff, 2003, document the sensitivity of exchange rates to commodity prices in the cases of Australia and New Zealand. Frankel, 2005b, does Kazakhstan, and Frankel, 2007, South Africa.)
} 
- a resultant shift of labor and land out of non-export-commodity traded goods (pulled by the more attractive returns in the export commodity and in non-traded goods and services), and

- a current account deficit (thereby incurring international debt that may be difficult to service when the commodity boom ends ${ }^{44}$ ).

When crowded-out non-commodity tradable goods are in the manufacturing sector, the feared effect is deindustrialization. ${ }^{45}$ In a real trade model, the reallocation of resources across tradable sectors, e.g., from manufactures to oil, may be inevitable regardless of macroeconomics. But the movement into non-traded goods is macroeconomic in origin.

What makes the Dutch Disease a “disease?” One interpretation, particularly relevant if the complete cycle is not adequately foreseen, is that the process is all painfully reversed when the world price of the export commodity goes back down. A second interpretation is that, even if the perceived longevity of the increase in world price turns out to be accurate, the crowding out of non-commodity exports is undesirable, perhaps because the manufacturing sector has greater externalities for long-run growth (as in Matsuyama, 1992). But the latter view is really just another name for the Natural Resource Curse, discussed in the preceding section; it has nothing to do with cyclical fluctuations per se.

The Dutch Disease can arise from sources other than a rise in the commodity price. Other examples arise from commodity booms due to the discovery of new deposits or some other expansion in supply, leading to a trade surplus via exports or a capital account surplus via inward investment to develop the new resource. In addition, the term is also used by analogy for other sorts of inflows such as the receipt of transfers (foreign aid or remittances) or a stabilization-induced capital inflow. In all cases, the result is real appreciation and a shift into nontradables, and away from (non-booming) tradables. Again, the real appreciation takes the form of a nominal appreciation if the exchange rate is flexible, and inflation if the exchange rate is fixed.

\section{b. Procyclicality}

Volatility in developing countries arises both from foreign shocks, such as the fluctuations in the price of the export commodity discussed above, and also from

\footnotetext{
${ }^{44}$ Manzano and Rigobon (2008) show that the negative Sachs-Warner effect of resource dependence on growth rates during 1970-1990 was mediated through international debt incurred when commodity prices were high. Arezki and Brückner (2010a) find that commodity price booms lead to increased government spending, external debt and default risk in autocracies, and but do not have those effects in democracies. Arezki and Brückner (2010b) find that the dichotomy extends also to the effects on sovereign bond spreads paid by autocratic versus democratic commodity producers .

${ }^{45}$ In Gylfason, Herbertsson and Zoega (1999), the real appreciation lowers long-term growth because the primary sector does not experience learning by doing as the secondary sector does.
} 
domestic macroeconomic and political instability. Although most developing countries in the 1990s brought under control the chronic runaway budget deficits, money creation, and inflation, that they experienced in the preceding two decades, most are still subject to monetary and fiscal policy that is procyclical rather than countercyclical: they tend to be expansionary in booms and contractionary in recessions, thereby exacerbating the magnitudes of the swings. The aim should be to moderate them -- the countercyclical pattern that the models and textbooks of the decades following the Great Depression originally hoped discretionary policy would take. Often income inequality and populist political economy are deep fundamental forces underlying the observed procyclicality.

That developing countries tend to experience larger cyclical fluctuations than industrialized countries is only partly attributable to commodities. It is also in part due to the role of factors that "should" moderate the cycle, but in practice seldom operate that way: procyclical capital flows, procyclical monetary and fiscal policy, and the related Dutch Disease. If anything, they tend to exacerbate booms and busts instead of moderating them. The hope that improved policies or institutions might reduce this procyclicality makes this one of the most potentially fruitful avenues of research in emerging market macroeconomics.

\section{c. The procyclicality of capital flows to developing countries}

According to the theory of intertemporal optimization, countries should borrow during temporary downturns, to sustain consumption and investment, and should repay or accumulate net foreign assets during temporary upturns. In practice, it does not always work this way. Capital flows are more often procyclical than countercyclical. ${ }^{46}$ Most theories to explain this involve imperfections in capital markets, such as asymmetric information or the need for collateral.

As developing countries evolve more market-oriented financial systems, the capital inflows during the boom phase show up increasingly in prices for land and buildings, and also in prices of financial assets. Prices of equities and bonds (or the reciprocal, the interest rate) are summary measures of the extent of speculative enthusiasm, often useful for predicting which countries are vulnerable to crises in the future.

In the commodity and emerging market boom of 2003-2008, net capital flows typically went to countries with current account surpluses, especially Asians and commodity producers in the Middle East and Latin America, where they showed up in record accumulation of foreign exchange reserves. This was in contrast to the two previous cycles, 1975-1981 and 1990-97, when the capital flows to developing countries largely went to finance current account deficits.

One interpretation of procyclical capital flows is that they result from procyclical fiscal policy: when governments increase spending in booms, some of the deficit is financed by borrowing from abroad. When they are forced to cut spending in

${ }^{46}$ Kaminsky, Reinhart, and Vegh (2005); Reinhart and Reinhart (2009); Gavin, Hausmann, Perotti and Talvi (1996); and Mendoza and Terrones (2008). 
downturns, it is to repay some of the excessive debt that they incurred during the upturn. Another interpretation of procyclical capital flows to developing countries is that they pertain especially to exporters of agricultural and mineral commodities, particularly oil. We consider procyclical fiscal policy in the next sub-section, and return to the commodity cycle (Dutch disease) in the one after.

\section{d. The procyclicality of fiscal policy}

Many authors have documented that fiscal policy tends to be procyclical in developing countries, especially in comparison with industrialized countries. ${ }^{47}$ Most studies look at the procyclicality of government spending, because tax receipts are particularly endogenous with respect to the business cycle. An important reason for procyclical spending is precisely that government receipts from taxes or royalties rise in booms, and the government cannot resist the temptation or political pressure to increase spending proportionately, or more than proportionately.

Procyclicality is especially pronounced in countries that possess natural resources and where income from those resources tends to dominate the business cycle. Among those focusing on the correlation between commodity booms and spending booms is Cuddington (1989). Sinnott (2009) finds that Latin American countries are sufficiently commodity-dependent that government revenue responds significantly to commodity prices. Spending also responds positively in the case of hydrocarbon producers. ${ }^{48}$

Two large budget items that account for much of the increased spending from oil booms are investment projects and the government wage bill. Regarding the first budget item, investment in infrastructure can have large long-term pay-off if it is well designed; too often in practice, however, it takes the form of white elephant projects, which are stranded without funds for completion or maintenance, when the oil price goes back down (Gelb, 1986). Regarding the second budget item, Medas and Zakharova (2009) point out that oil windfalls have often been spent on higher public sector wages. They can also go to increasing the number of workers employed by the government. Either way, they raise the total public sector wage bill, which is hard to reverse when oil prices go back down. Figures 2 and 3 plot the public sector wage bill for two oil producers against primary product prices over the preceding three years: Iran and Indonesia. There is a clear positive relationship. That the relationship is strong with a three-year lag illustrates the problem: oil prices may have fallen over three years, but public sector wages cannot easily be cut nor workers laid off. ${ }^{49}$

Figure 2: Iran’s Government Wage Bill Is Influenced by Oil Prices Over Preceding 3 Years

$(1974,1977-1997$.

47 Cuddington (1989), Tornell and Lane (1999), Kaminsky, Reinhart, and Vegh (2004), Talvi and Végh (2005), Alesina, Campante and Tabellini (2008), Mendoza and Oviedo (2006), Ilzetski and Vegh (2008) and Medas and Zakharova (2009). For Latin America in particular: Gavin and Perotti (1997).

${ }^{48}$ Especially Argentina, Ecuador and Venezuela (Figure 4). She does not find that the spending relationshiop is statistically significant, but this may be due to insufficient data. ${ }^{49}$ Source for graphs: Frankel (2005b). Arezki and Ismail (2010) find that current government spending increases in boom times, but is downward-sticky. 


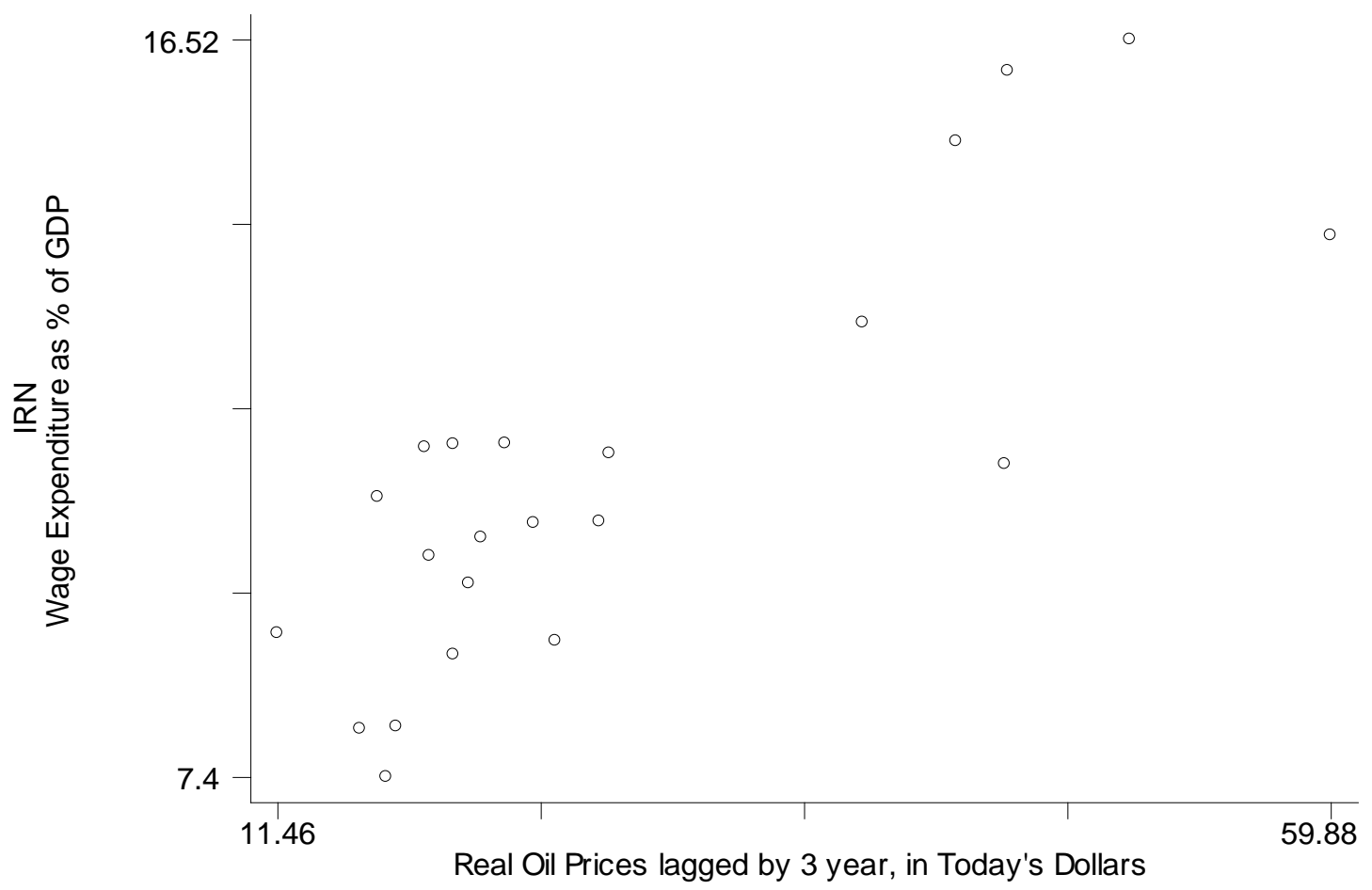

Fig. 3: Indonesia’s Government Wage Bill Is Influenced by Oil Prices Over Preceding 3 Years (1974, 1977-97)

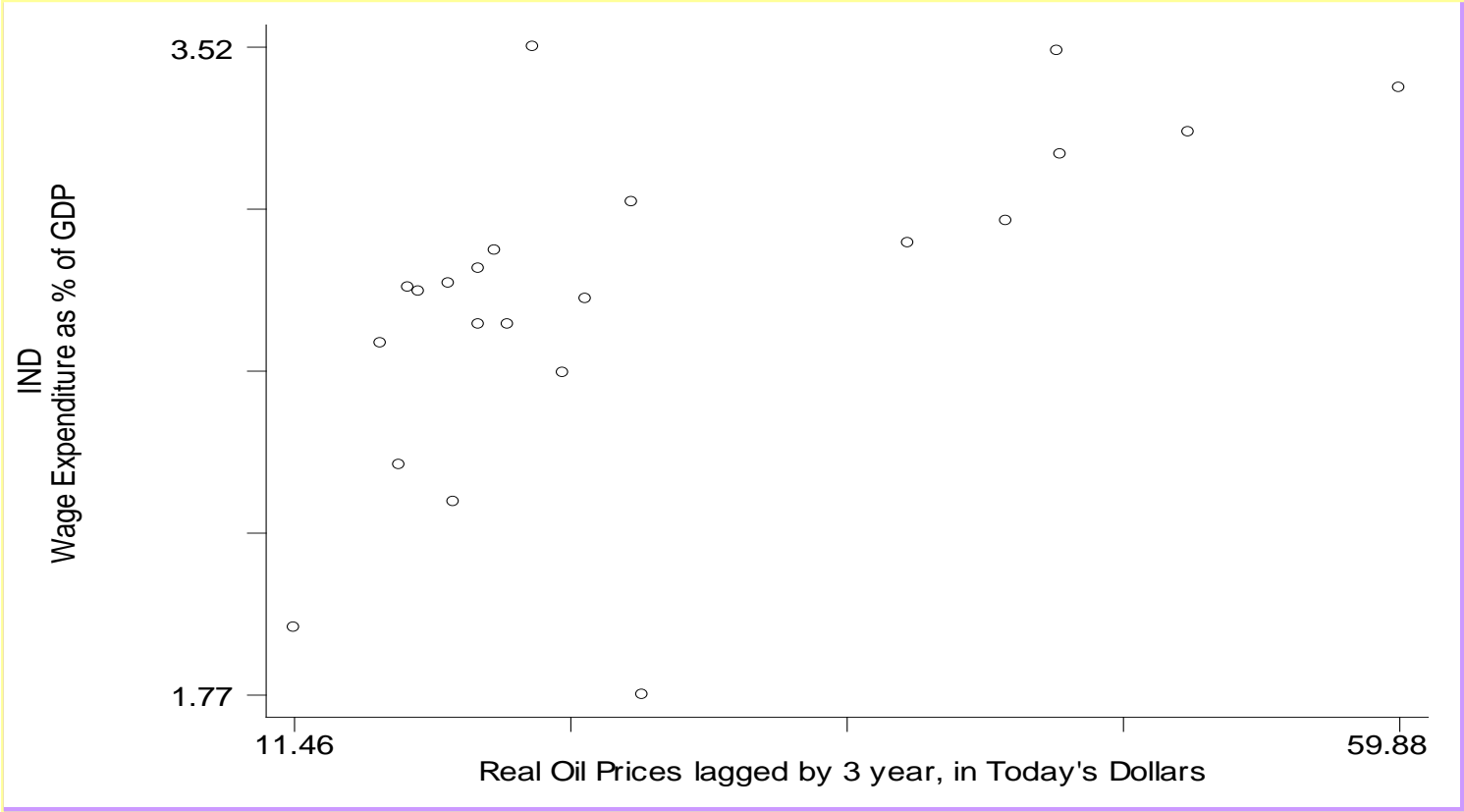

\section{Institutions and Policies to Address the Natural Resource Curse}


A wide variety of measures have been tried to cope with the commodity cycle. ${ }^{50}$ Some work better than others.

\section{a. Institutions That Were Supposed to Stabilize But Have Not Worked}

A number of institutions have been implemented in the name of reducing the impact on producer countries of volatility in world commodity markets. Most have failed to do so, and many have had detrimental effects.

\section{i. Marketing boards}

Examples of marketing boards are the systems implemented around the time of independence in some East and West African countries, requiring that all sales of cocoa and coffee pass through the government agency. The original justification was to stabilize the price to domestic producers, symmetrically setting a price above world prices when the latter were low and setting a domestic price below world prices when the latter were high. That in turn would have required symmetrically adding to government stockpiles when world prices were low, and running them down when world prices were high.

In practice, the price paid to cocoa and coffee farmers, who were politically weak, was always below the world price. The rationale eventually shifted from stabilization to taxation of the agricultural sector (which was thought to be inelastic in its supply behavior), and subsidization of the industrial sector. But industrialization did not happen. Rather, the coffee and cocoa sectors shrank. Commodity marketing boards were a failure.

\section{ii. Taxation of commodity production}

Some developing countries subject their mineral sectors to high levels of taxation and regulation, particularly where foreign companies are involved, which can discourage output. Of course some taxation and regulation may be appropriate on environmental grounds. One can understand, moreover, the desire to avoid past experiences where multinational companies were able to walk away with the lion's share of the profits. But when Bolivia, Mexico, and Venezuela explicitly prohibit or discourage foreign involvement in the development of their mineral resources, motivated by populist nationalism, the danger is that they end up "killing the goose that lays the golden egg."

\section{iii. Producer subsidies}

More often in rich countries the primary producing sector has political power on its side. Then the stockpiles act as a subsidy rather than a tax. An example is the Common Agricultural Policy in Europe. Subsidies also go to coal miners in Germany, oil

${ }^{50}$ E.g., Davis, et al (2003) and Sachs (2007). 
companies with cheap leases on federal lands in the United States, and agricultural and energy sectors in many other countries.

\section{iv. Other government stockpiles}

Some governments maintain stockpiles under national security rationales, such as American's Strategic Petroleum Reserve. One drawback is that decisions regarding the management of government stockpiles are often made subject to political pressure, rather than to maximize the objective of insulating against the biggest shocks. Another drawback is undermining of the incentive for private citizens to hold stockpiles.

In some countries where prices of fuel to consumers are a politically sensitive issue, the incentive for the private sector to maintain inventories is undercut in any case, by the knowledge that in the event of a big increase in the price of the commodity, the inventory-holder will probably not be allowed to reap the benefits. If this political economy structure is a given, then there is a valid argument for the government to do the stockpiling.

\section{v. Price controls for consumers}

In developing countries, the political forces often seek to shield consumers against increases in prices of basic food and energy through price controls. If the country is a producer of the crop or mineral in question, then the policy tool to insulate domestic consumers against increases in the world price may be export controls. (Examples include Argentina's wheat and India's rice in 2008.) If the country is an importer of the crop or mineral in question, then either the commodity is rationed to domestic households or else the excess demand at the below-market domestic price is made up by imports. Capped exports from the exporting countries and price controls in the importing countries both work to exacerbate the magnitude of the upswing of the price for the (artificially reduced) quantity that is still internationally traded. If the producing and consuming countries in the rice market could cooperatively agree to refrain from government intervention, volatility could be lower, rather than higher, even though intervention is justified in the name of reducing price volatility.

\section{vi. OPEC and other International cartels}

In a world of multiple producers for a given commodity, efforts by producing countries to raise the price or reduce the volatility would logically require the cooperation of all or most of the producers. Each is strongly tempted to defect, raising output to take advantage of the higher price. Most attempts at forming international cartels have failed within a few years. ${ }^{51}$

The institution that endures decade after decade is OPEC. It is not clear whether its attempts to raise the average or reduce the variability of the price have succeeded. Some of the most abrupt decreases as well as increases in the world price over the last half century have arguably been attributable to changes in OPEC's internal dynamics (increased collusion after the Arab Oil Embargo of 1973, followed by a breakdown in the

51 Pindyck (1979) and Gilbert (1996). 
1980s when members stopped obeying their agreed quotas). Meanwhile, many new oil producers have cropped up outside of OPEC, suggesting a diminution in its collective monopoly power even when it is acting in unison.

\section{b. Devices to share risks}

It is probably best to accept that commodity prices will be volatile, and to seek to establish institutions that will limit adverse economic effects that result from the volatility. In this section we consider microeconomic policies to minimize exposure to risk, the sort of short-term volatility discussed in part II of the paper. (We will subsequently consider macroeconomic policies to minimize the costs of big medium-term swings of the sort associated with the Dutch Disease.)

Three devices for avoiding exposure to short-term volatility are promising. One is relevant for energy exporters who sign contracts with foreign companies, another for producers that do their own selling, and a third for governments dependent on energy revenues.

\section{i. Price setting in contracts with foreign companies}

Price setting in contracts between energy producers and foreign companies is often plagued by a problem that is known to theorists as dynamic inconsistency. ${ }^{52}$ The pattern has been repeated in many countries. A price is set by contract. Later the world price goes up, and then the government wants to renege. It doesn't want to give the company all the profits and, in a sense, why should it? Certainly the political pressures are typically strong.

But this is a "repeated game." The risk that the locals will renege makes foreign companies reluctant to do business in the first place. It limits the amount of capital available to the country, and probably raises the price of that capital. The process of renegotiation can have large transactions costs, such as interruptions in the export flow.

It has become such a familiar pattern that it seems more contracts ought to have been designed to be robust with respect to this inconsistency, by making the terms explicitly dependent on future market conditions. ${ }^{53}$ The simplest device would be indexed contracts, where the two parties agree ahead of time, "if the world price goes up ten per cent, then the gains are split between the company and the government" in some particular proportion. Indexation shares the risks of gains and losses, without the costs of renegotiation or the damage to a country's reputation from reneging on a contract.

\section{ii. Hedging in commodity futures markets}

Producers, whether private or public, often sell their commodities on international spot markets. They are thus exposed to the risk that the dollar price of a given export

\footnotetext{
52 Helm (2010).

53 Humphreys, Sachs, and Stiglitz (2007, p. 323).
} 
quantity will rise or fall. In many cases, the producer can hedge the risk by selling that quantity on the forward or futures market. ${ }^{54}$ As with indexation of the contract price, hedging means that there is no need for costly renegotiation in the event of large changes in the world price. The adjustment happens automatically. Mexico has hedged its oil revenues in this way. ${ }^{55}$ One possible drawback, especially if it is a government ministry doing the hedging, is that the minister may receive little credit for having saved the country from disaster when the world price plummets, but will be excoriated for having sold out the national patrimony when the world price rises.

\section{iii. Denomination of debt in terms of commodity prices}

An excellent idea, which has unaccountably never managed to catch on, is for a mineral-producing company or government to index its debt to the price of the commodity. Debt service obligations automatically rise and fall with the commodity price. This would save developing countries from the kinds of crises that Latin Americans faced in 1982 and Asians in 1997, when the dollar prices of their exports fell at the same time that the dollar interest rate on their debts went up. The result for many countries was an abrupt deterioration of their debt service ratios and a balance of payments crisis. This would not have happened if their debts had been indexed to their commodity prices - oil for such borrowers as Ecuador, Indonesia, Iran, Mexico, Nigeria, and Russia. As with contract indexation and hedging, the adjustment in the event of fluctuations in the world price is automatic.

When officials in commodity producing countries are asked why they have not tried indexing their bonds (or loans) to the price of their export commodity, the usual answer is that they believe there would not be enough demand from the market (or enough interest from banks). It is true that a market needs a certain level of liquidity in order to thrive, and that it can be hard for a new financial innovation to get over the volume threshold. But it used to be said that foreigners would not buy bonds denominated in the currencies of emerging market countries. ${ }^{56}$ Yet in recent years, more and more developing countries have found that they could borrow in their own currency if they tried. Investor receptivity to oil-denominated bonds is potentially larger. There are obvious natural ultimate customers for oil-linked bonds: electric utilities and the many other companies in industrialized countries who are as adversely affected by an increase in the world price of oil as the oil exporters are by a decrease. This is a market waiting to be born.

\section{c. Monetary policy}

54 Alquist and Killian (2010).

55 E.g., "Mexico Buys \$1bn Insurance Policy Against Falling Oil Prices,” Financial Times, Dec. 9, 2009.

56 Eichengreen and Hausmann (1999) said that the “original sin” plaguing emerging markets was the reluctance of foreign investors to expose themselves in local currency. 
We now move from ideas for institutions to address the risk created by high shortterm price volatility to ideas for macroeconomic management of medium-term swings. We begin with monetary and exchange rate policy to manage the Dutch Disease.

\section{i. Fixed vs. floating exchange rates}

Fixed and floating exchange rates each have their advantages. The main advantages of a fixed exchange rate are, first, that it reduces the costs of international trade, and second that it is a nominal anchor for monetary policy, helping the central bank achieve low-inflation credibility. The main advantage of floating, for a commodity producer, is that it often provides automatic accommodation of terms of trade shocks: during a commodity boom, the currency tends to appreciate, thereby moderating what would otherwise be a danger of excessive capital inflows and overheating of the economy, and the reverse during a commodity bust.

A reasonable balancing of these pros and cons, appropriate for many middle-size middle-income countries, is an intermediate exchange rate regime such as managed floating or a target zone (a band). The mid-point of the band can be defined as a basket of major currencies, rather than a simple bilateral parity against the dollar or euro, if neither the United States nor euroland is the dominant trading partner currency. In the booming decade that began in 2001, many followed the intermediate regime, in between a few commodity producers in the floating corner (Chile and Mexico) and a few in the firmly fixed corner (Gulf oil producers, Ecuador). While they officially declared themselves as floating (often as part of Inflation Targeting), in practice these intermediate countries intervened heavily, taking perhaps half the increase in demand for their currency in the form of appreciation but half in the form of increased foreign exchange reserves. Examples among commodity-producers include Kazakhstan, South Africa, Russia, and many others. ${ }^{57}$ Particularly at the early stages of a commodity boom, when one has little idea whether it is permanent or not, there is a good case for intervention in the foreign exchange market, adding to reserves (especially if the alternative is abandoning an established successful exchange rate target), and perhaps for awhile attempting to sterilize the inflow to prevent rapid expansion in the money supply. In subsequent years, if the increase in world commodity prices looks to be long-lived, there is a stronger case for accommodating it through nominal and real appreciation of the currency.

It is especially important in developing countries, where institutions tend to have lower credibility than in advanced countries, that the public's expectations of inflation be anchored by some nominal target by which the central bank asks to be judged. If the exchange rate is not to be that nominal target, then some other anchor variable should be chosen.

ii. Alternative nominal anchors

57 The tendency for official floaters to intervene heavily in practice to dampen exchange rate fluctuations was named "fear of floating," by Calvo and Reinhart (2002). 
Three candidates for nominal anchor have had ardent supporters in the past, but are no longer prominently in the running. They are: the price of gold, as under the $19^{\text {th }}$ century gold standard; the money supply, the choice of monetarists; and National Income, the choice of many mainstream economists in the 1980s.

Central bankers and monetary economists alike have, in recent years, considered Inflation Targeting to be the preferred approach -- or at least the preferred alternative to fixed exchange rates, which may be appropriate for very small very open countries. Although there are different interpretations of Inflation Targeting, some more flexible than others, they all tend to take the CPI as the index to be targeted, and to explicitly disavow the exchange rate as a target (or domestic commodity prices, or asset prices). ${ }^{58}$

Inflation Targeting (IT) has a particular disadvantage for commodity producing countries: it is not robust with respect to changes in the terms of trade. Consider a fall in world market conditions for the export commodity, a decrease in the dollar price. It has a negative impact on both the balance of payments and the level of economic activity. It would be desirable for monetary policy to loosen and the currency to depreciate, to boost net foreign demand and thereby restore external balance and internal balance. But CPI targeting tells the central bank to keep monetary policy sufficiently tight that the currency does not depreciate, because otherwise import prices will rise and push the CPI above its target. Conversely if the world price for the export commodity goes up, a CPI target prevents a needed appreciation of the currency because it would lower import prices and push the CPI below its target.

I have in the past proposed for commodity producers a regime that I call Peg the Export Price (PEP). The proposal is that monetary policy be guided by the rule to keep the local-currency price of the export commodity stable from day to day. For an oilproducer, every day that the dollar price of oil goes up $1 \%$, monetary policy would allow the dollar price of the local currency to go up 1\%, thereby keeping the local price of oil unchanged. The argument is that PEP combines the best of both worlds: it automatically accommodates terms of trade changes, as floating is supposed to do, while simultaneously abiding by a pre-announced nominal anchor, as IT is supposed to do. Simulations show, for example, that if Indonesia and Russia had been on a PEP regime, they would have automatically experienced necessary depreciation in the late 1990s, when oil prices fell, without having to go through the painful currency crises that these two countries in fact experienced in 1998. ${ }^{59}$ An additional selling point is that because PEP moderates swings in the real value of export revenue, expressed in terms of

58 Two qualifications to the apotheosis of the CPI. First, some versions phrase targets in terms of "headline CPI" and some in terms of "core CPI," typically excluding food and energy. Second, proponents often say that it is alright for the central bank to pay attention to the exchange rate (or commodity prices or asset prices), but only to the extent that it helps achieve its longer run objective of price stability. Neither of these two qualifications matters for present purposes.

${ }^{59}$ Frankel (2003a). A more practical variation, for a country already contemplating a basket peg, is to include the commodity in the basket. Middle Eastern oil exporters, for example, could have a basket peg with $1 / 3$ weight on the dollar, $1 / 3$ on the euro, and 1/3 on a barrel of oil. (Frankel, “A Crude Proposal to Peg the Dinar,” Financial Times, June 13, 2003.) 
purchasing power over domestic goods and services, it would reduce the tendency for governments to increase spending excessively in boom times and symmetrically cut it in busts.

PEP in its pure form is a rather extreme proposal, which may account for the lack of guinea pigs willing to try it. If the non-commodity export sector is not small, or if policy-makers want it to become larger, then PEP has the disadvantage of fully transferring the burden of exogenous fluctuations in world commodity prices to variability in domestic prices of non-commodity exports. It is not clear that this is an improvement over continuing to let the fluctuations show up as variability in domestic prices of the commodity export. A more practical version of the proposal would be to target a more comprehensive index of export prices rather than a single export price (Peg the Export Price Index). ${ }^{60}$ A still more moderate version would target an even more comprehensive index of domestic production prices, including nontraded goods, such as the Producer Price Index, GDP deflator, or a specially constructed index. ${ }^{61}$ The important point is to include export commodities in the index and exclude import commodities, whereas the CPI does it the other way around.

\section{d. Institutions to make national saving procyclical}

We have noted the Hartwick rule, which says that rents from a depletable resource should be saved, against the day when deposits run out. At the same time, traditional macroeconomics says that government budgets should be countercyclical: running surpluses in booms and spending in recessions. Commodity producers tend to fail in both these principles: they save too little on average and all the more so in booms. Thus some of the most important ways to cope with the commodity cycle are institutions to insure that export earnings are put aside during the boom time, into a commodity saving fund, perhaps with the aid of rules governing the cyclically adjusted budget surplus. ${ }^{62}$

i. Rules for the budget deficit: The example of Chile.

As of June 2008, the President of Chile, Michele Bachelet, and her Finance Minister, Andres Velasco, had the lowest approval ratings of any President or Finance Minister, respectively, since the return of democracy. There were undoubtedly multiple reasons for this, but one was popular resentment that the two had resisted intense pressure to spend the soaring receipts from copper exports. One year later, in the summer of 2009, the pair had the highest approval ratings of any President and Finance Minister. Why the change? Not an improvement in overall economic circumstances: in the meantime the global recession had hit. Copper prices had fallen abruptly. But the government had increased spending sharply, using the assets that it had acquired during the copper boom, and thereby moderating the downturn. Saving for a rainy day made the officials heroes, now that the rainy day had come. Chile has achieved what few commodity-producing developing countries have achieved: a truly countercyclical fiscal policy. Some credit

60 Frankel (2005a, 2008c).

61 Frankel (2009).

62 Davis et al (2001a,b, 2003). 
should go to previous governments, who initiated an innovative fiscal institution. ${ }^{63}$ But much credit should go to the Bachelet government, which enshrined the general

framework in law and abided by it when it was most difficult to do so politically. . ${ }^{64}$

Chile's fiscal policy is governed by a set of rules. The first one is a target for the overall budget surplus -- originally set at $1 \%$ of GDP, then lowered to $1 / 2 \%$ of GDP, and again to 0 in 2009. This may sound like the budget deficit ceilings that supposedly constrain members of euroland (deficits of $3 \%$ of GDP under the Stability and Growth Pact) or like the occasional U.S. proposals for a Balanced Budget Amendment (zero deficit). But those attempts have failed, because they are too rigid to allow the need for deficits in recessions, counterbalanced by surpluses in good times. The alternative of letting politicians explain away any deficits by declaring them the result of slower growth than expected also does not work, because it imposes no discipline.

Under the Chilean rules, the government can run a deficit larger than the target to the extent that:

(1) output falls short of potential, in a recession, or

(2) the price of copper is below its medium-term (10-year) equilibrium,

with the key institutional innovation that there are two panels of experts whose job it is each mid-year to make the judgments, respectively, what is the output gap and what is the medium term equilibrium price of copper (also the same for molybdenum). Thus in the copper boom of 2003-2008 when, as usual, the political pressure was to declare the increase in the price of copper permanent thereby justifying spending on a par with export earnings, the expert panel ruled that most of the price increase was temporary so that most of the earnings had to be saved. This turned out to be right, as the 2008 spike was indeed temporary. As a result, the fiscal surplus reached almost $9 \%$ when copper prices were high. The country paid down its debt to a mere $4 \%$ of GDP and it saved about $12 \%$ of GDP in the sovereign wealth fund. This allowed a substantial fiscal easing in the recession of 2008-09, when the stimulus was most sorely needed.

Any country, but especially commodity-producers, could usefully apply variants of the Chilean fiscal device. (Ecuador has a similar rule for its oil revenues.) Given that many developing countries are more prone to weak institutions, a useful reinforcement of the Chilean idea would be to formalize the details of the procedure into law and give the members of the panels legal independence. There could a requirement regarding the professional qualifications of the members and laws protecting them from being fired, as there are for governors of independent central banks. The principle of a separation of decision-making powers should be retained: the rules as interpreted by the panels determine the total amount of spending or budget deficits, while the elected political leaders determine how that total is allocated.

\footnotetext{
${ }^{63}$ Page 11 of International Monetary Fund, Chile 2005 Article IV Consultation, IMF Country Report 05/013 (September 2005).

64 It introduced a Fiscal Responsibility Bill in 2006, which gave legal force to the role of the structural budget. The bill also created a Pension Reserve Fund and a Social and Economic Stabilization Fund, the latter a replacement for the existing Copper Stabilization Funds.
} 


\section{ii. Commodity funds or Sovereign Wealth Funds}

Many natural resource producers have Commodity Funds, to invest savings for future welfare, often in global portfolios. The oldest and biggest Commodity Funds are in the Persian Gulf, belonging to Kuwait and the United Arab Emirates. Some highly successful non-commodity exporters in Asia have established such funds too. When China joined the club in 2007, they received a new name, Sovereign Wealth Funds, and a lot of new scrutiny.

It has been pointed out that the mere creation of a commodity fund, in itself, does not necessarily do anything to insure that politicians will not raid the fund when it is flush. ${ }^{65}$ Two standard recommendations are that the funds be transparently and professionally run, and that they be given clear instructions that politics should not interfere with their objective of maximizing the financial wellbeing of the country. The Norwegian State Petroleum Fund (now called the Norwegian Pension Fund) is often held up as a model. ${ }^{66}$ But in fact Norway's legal system puts few restrictions on what policymakers can do, and the fund is managed with political objectives that sometimes go unnoticed when held up as an example for developing countries to emulate. ${ }^{67}$

For most countries, it would be best to have rules dictating the cap on spending out of the fund. The commodity fund of Sao Tome and Principe newly established in 2004, includes extensive restrictions guiding how the oil revenues are to be saved, invested, or spent. (Outflows legally cannot exceed the highest amount that could be sustained in perpetuity.)

Humphreys and Sandhu (2007) recommend that spending go through the regular budget, so that they do not become any politicians' private "slush funds." There can be advantages in earmarking the commodity funds for specific good causes such as education, health, or retirement support for a future generation. If the political constituents know how the money is to be spent, they may be both more tolerant of the initiative to save it in the first place and more vigilant with respect to transgressions by politicians wishing to raid the kitty to spend on armies or palaces.

\section{iii. Reserve accumulation by central banks}

One way that countries save in the aggregate during booms, in order to be able to dissave in busts, is for central banks to accumulate international reserves via foreign exchange intervention. Economists have regarded this as a sub-optimal mechanism: if the goal is smoothing spending over time, as opposed to stabilization of the exchange

65 Davis et al (2001b) and Humphreys and Sandhu (2007). In countries with few checks and balances, large yearly changes in oil revenues tend to lead to large yearly changes in government consumption.

${ }_{66}^{6}$ Holmøy (2010).

67 The political objectives are intended to serve the cause of social responsibility. "Norway Proposes to Do Well in Its Investments by Doing Good,” New York Times, May 4, 2007, p. C4; “Norway Finds Virtue (and Value) in Transparency,” New York Times, Sept. 27, 2008., p.B2. But social responsibility includes boycotting stock in Wal-Mart (a company that many American economists consider beneficial to people of lower income). 
rate, holding the assets in the form of foreign exchange reserves has disadvantages. First, the reserves (typically US treasury bills) do not earn a high return. Second, increases in reserves can lead to rapid monetary expansion (if not sterilized) and thereby to inflation. Thus a central bank that already has enough reserves, judged by precautionary and monetary criteria, should consider selling some of the foreign exchange to the country's Natural Resource Fund. But if the Central Bank has political independence and the NRF does not, that may be a reason to leave the reserves where they cannot be raided.

iv. Reducing net private capital inflows during booms

If foreign exchange reserves are piling up to excessive levels, there are other ways to reduce the balance of payments surplus and facilitate national saving. One is for the government deliberately to pay down debt, especially short-term debt. Another is to remove any remaining controls on the ability of domestic citizens to invest abroad. A third is to place controls on capital inflows, especially short-term inflows.

\section{v. Lump sum distribution}

The Alaska Permanent Fund saves earnings from the state's oil sector. Alaska state law says that the Fund must distribute half of the investment earnings on an equal per capita basis. The theory is that the citizens know how to spend their money better than does their government. Certainly the system gives Alaskans a good reason to feel that they are full stakeholders in the Fund. Sala-I-Martin and Subramanian (2003) suggest that Nigeria should similarly distribute its oil earnings on a equal per capita basis; Birdsall and Subramanian (2004) make the same proposal for Iraq. ${ }^{68}$

\section{e. Efforts to impose external checks}

All these institutions can fail if, as in some countries, the executive simply ignores the law and spends what he wants. In 2000 the World Bank agreed to help Chad, a new oil producer, to finance a new pipeline. The agreement stipulated that Chad would spend 72 per cent of its oil export earnings on poverty reduction (particularly health, education and road-building) and put aside 10 percent in a "future generations fund." ExxonMobil was to deposit the oil revenues in an escrow account at Citibank and the government was to spend them subject to oversight by an independent committee. But once the money started rolling in, the government (ranked by Transparency International as one of the two most corrupt in the world) reneged on the agreement. ${ }^{69}$

68 Ross (2007).

69 "Chad Backs Out of Pledge to use Oil Wealth to Reduce Poverty," New York Times, Dec. 13, 2005, p. A15; "World Bank Suspends Loans to Chad Over Use of Oil Money," NYT, Jan. 7, 2006; “The 'Resource Curse’ Anew: Way a Grand World Bank Oil Project Has Fast Run Into the Sand,” Financial Times, Jan. 23, 2006, p. 13; “World Bank Ends Effort to Help Chad Ease Poverty," New York Times, September 11, 2008; "Breaking the Bank: A Vaunted Model Development Project Goes Awry,” The Economist, Sept. 26, 2008, p. 63. 
Evidently International Financial Institutions would have to go beyond the Chad model if local rulers are to be prevented from abuse. The Extractive Industries Transparency Initiative, launched in 2002, includes the principle "Publish What You Pay,” under which international oil companies commit to make known how much they pay governments for oil, so that the public at least has a way of knowing when large sums disappear. Legal mechanisms adopted by Sao Tome and Principe void contracts if information relating to oil revenues is not made public. Further proposals would give extra powers to a global clearing house or foreign bank where the Natural Resource Fund is located, such as freezing accounts in the event of a coup. ${ }^{70}$ Perhaps that principle could be generalized: it may be that well-intentioned politicians spend oil wealth quickly out of fear that their successors will misspend whatever is left, in which case the adoption of an external mechanism that constrains spending both in the present in the future might not be an unacceptable violation of sovereignty.

\section{Summary}

Much theoretical reasoning and statistical evidence suggests that possession of natural resources such as hydrocarbons, minerals, and perhaps agricultural endowments, can confer negative effects on a country, along with the benefits. This paper has considered six channels whereby natural resources might possibly have negative effects on economic performance. The first, the Prebisch-Singer hypothesis of a negative longterm trend in commodity prices is counteracted by theoretical arguments for a positive trend, and empirical findings that there is no consistent trend either way. But the other five channels each have at least some truth to them.

(1) Commodity price volatility is high, which imposes risk and transactions costs. (2) Specialization in natural resources can be detrimental to growth if it crowds out the manufacturing sector and the latter is the locus of positive externalities. (3) Mineral riches can lead to civil war, an obstacle to development. (4) Endowments of "point source" commodities (oil and minerals and some crops) can lead to poor institutions, such as corruption, inequality, class structure, chronic power struggles, and absence of rule of law and property rights. Natural resource wealth can also inhibit the development of democracy, though there is not good evidence that democracy per se (as opposed to openness, economic freedom, decentralization of decision-making, and political stability) leads to economic growth. (5) The Dutch Disease, resulting from a commodity boom, entails real appreciation of the currency and increased government spending, both of which expand nontraded goods and service sectors such as housing and render uncompetitive non-commodity export sectors such as manufactures. If and when world commodity prices go back down, adjustment is difficult due to the legacy of bloated government spending and debt and a shrunken manufacturing sector.

\footnotetext{
${ }^{70}$ Humphreys and Sandhu (2007, p. 224-227). During the period when Kuwait was occupied by an Iraqi invasion, access to Kuwaiti bank accounts in London stayed with the Kuwaitis.
} 
In recent years, a host of revisionists have questioned each of these five channels, as well as the bottom line that natural resource wealth is detrimental for economic growth. Some differences in econometric findings are attributable to whether economic performance is measured as the level of income or the rate of growth of income during the sample period. Others are due to whether the equation conditions on related variables when it tests the influence of the channel in question. The revisionists often emphasize that resource extraction is endogenous, and that it is wrong to treat data on mineral exports - the usual measure of "resource dependence" -- as if they represent geographic endowments.

From a policy viewpoint, we do not necessarily need to settle these questions. It is clear that some resource-rich countries do surprisingly poorly economically, while others do well. We have noted examples of both sorts: countries such as Norway, Botswana and Chile that have done very well with their endowments (oil, diamonds and copper, respectively) versus others such as Sudan, Bolivia and the Congo that have done less well. The Natural Resource Curse should not be interpreted as a rule that resourcerich countries are doomed to failure. The question is what policies to adopt to increase the chances of prospering. It is safe to say that destruction or renunciation of resource endowments, to avoid dangers such as the corruption of leaders, will not be one of these policies. Even if such a drastic action would on average leave the country better off, which seems unlikely, who would be the policy-maker to whom one would deliver such advice?

The paper concludes with a list of ideas for institutions designed to address aspects of the resource curse and thereby increase the chance of economic success. Some of the ideas that most merit consideration by countries rich in oil or other natural resources are as follows.

1. Include in contracts with foreign purchasers clauses for automatic adjustment of the price if world market conditions change.

2. Hedge export proceeds in commodity futures markets.

3. Denominate debt in terms of commodity prices.

4. Allow some nominal currency appreciation in response to an increase in world prices of the commodity, but also add to foreign exchange reserves, especially at the early stages of the boom when it may prove to be transitory.

5. If the monetary regime is to be Inflation Targeting, consider using as the target, in place of the standard CPI, a price measure that puts greater weight on the export commodity, such as an index of export prices or producer prices.

6. Emulate Chile: to avoid excessive spending in boom times, allow deviations from a target surplus only in response to output gaps and longlasting commodity price increases, as judged by independent panels of experts rather than politicians.

7. Commodity Funds should be transparently and professionally run, with rules to govern the payout rate and with insulation of the managers from political pressure in their pursuit of the financial wellbeing of the country. 
8. When spending oil wealth, consider lump-sum distribution on an equal per capita basis.

9. An external agent, for example a financial institution that houses the Commodity Fund, could be mandated to provide transparency and to freeze accounts in the event of a coup.

Needless to say, policies and institutions have to be tailored to local circumstances, country by country. But with good intentions and innovative thinking, there is no reason why resource-rich countries need fall prey to the curse. 


\section{REFERENCES}

Acemoglu, Daron, Simon Johnson, James Robinson, 2001, "Colonial Origins of Comparative Development: An Empirical Investigation,” American Economic Review 91, no. 5, 1369-1401.

Acemoglu, Daron, Simon Johnson, James Robinson, 2002, "Reversal of Fortune: Geography and Institutions in the Making of the Modern World Income Distribution,” Quarterly Journal of Economics 117(4), 1231-1294.

Acemoglu, Daron, Simon Johnson, and James Robinson, 2003, " An African Success: Botswana," in In Search of Prosperity, edited by Dani Rodrik. Analytic Narratives in Economic Growth (Princeton: Princeton University Press).

Acemoglu, Daron, Simon Johnson, James Robinson, and Yunyong Thaicharoen, 2003, "Institutional Causes, Macroeconomic Symptoms: Volatility, Crises and Growth," Journal of Monetary Economics (Elsevier), vol. 50(1), pages 49-123, January.

Alesina, Alberto, Filipe Campante, and Guido Tabellini, 2008, "Why is Fiscal Policy Often Procyclical?” Journal of the European Economic Association, 6, no. 5, September, 1006-1036.

Alesina, Alberto, Sule Özler, Nouriel Roubini, and Phillip Swagel, 1996, "Political Instability and Economic Growth,” Journal of Economic Growth, Vol.1, No. 2, June.

Alexeev, Michael, and Robert Conrad, 2009, “The Elusive Curse of Oil,” Review of Economics and Statistics, 91, no. 3, 586-98.

Alquist, Ron, and Lutz Killian, 2010, "What Do We Learn from the Price of Crude Oil Futures?” Journal of Applied Econometrics, Volume 25, Issue 4, Pages 539 - 573 Alston, Lee, Gary Libecap and Robert Schneider, 1996, “The Determinants and Impact of Property Rights: Land Titles on the Brazilian Frontier” Journal of Law, Economics and Organization, 12, no. 1, 25-61.

Arezki, Rabah, and Markus Brückner, 2009, "Oil Rents, Corruption, and State Stability: Evidence From Panel Data Regressions," IMF Working Papers 09/267, International Monetary Fund.

Arezki, Rabah, and Markus Brückner, 2010a, "International Commodity Price Shocks, Democracy, and External Debt,” IMF Working Paper 10/53 (International Monetary Fund: Washington, DC).

Arezki, Rabah, and Markus Brückner, 2010b, "Resource Windfalls and Emerging Market Sovereign Bond Spreads: The Role of Political Institutions” (International Monetary Fund: Washington, DC). 
Arezki, Rabah, and Kareem Ismail, 2010, “Boom-Bust Cycle, Asymmetrical Fiscal Response and the Dutch Disease,” IMF WP/10/94 (International Monetary Fund: Washington DC), April.

Arezki, Rabah, and Frederick van der Ploeg, "Trade policies, institutions and the natural resource curse", Applied Economics Letters, forthcoming. From "Can the Natural Resource Curse Be Turned Into a Blessing? The Role of Trade Policies and Institutions,” IMF Working Paper 07/55, March.

Arezki, Rabah, and Frederick van der Ploeg, "Do natural resources depress income per capita?" Review of Development Economics, forthcoming. From IMF Working Paper $07 / 55$.

Auty, Richard, 1990, Resource-Based Industrialization: Sowing the Oil in Eight Developing Countries (Clarendon Press: Oxford).

Auty, Richard, 1993, Sustaining Development in Mineral Economies: The Resource Curse Thesis (Oxford University Press, New York).

Auty, Richard, 2001, Resource Abundance and Economic Development, World Institute for Development Economics Research (Oxford University Press).

Auty, Richard, 2007, "Patterns of Rent-Extraction and Deployment in Developing Countries: Implications for Governance, Economic Policy and Performance,” in G. Mavrotas and A. Shorrocks, editors, Advancing Development: Core Themes in Global Economics (Palgrave: London), 555-577.

Auty, Richard, 2009, “The Political Economy of Hydrocarbon Revenue Cycling in Trinidad and Tobago,” May, paper prepared for workshop on Myths and Realities of Commodity Dependence: Policy Challenges and Opportunities for Latin America and the Caribbean, World Bank, Sept. 17-18, 2009.

Balagtas, Joseph, and Matthew Holt, 2009, “The Commodity Terms of Trade, Unit Roots and Nonlinear Alternatives: A Smooth Transition Approach,” American Journal of Agricultural Economics, Volume 91 Issue 1, Pages 87 - 105.

Barbier, Edward, 2005, "Frontier Expansion and Economic Development," Contemporary Economic Policy 23, no. 2, April, 286-303.

Barbier, Edward, 2005, Natural Resources and Economic Development (Cambridge University Press: Cambridge UK).

Barbier, Edward, 2007, “Frontiers and Sustainable Economic Development," Environmental and Resource Economics, 37:271-295. 
Barro, Robert, 1991, "Economic Growth in a Cross Section of Countries,” Quarterly Journal of Economics, CVI, May, 407-444.

Barro, Robert, 1996, "Democracy and Growth,” Journal of Economic Growth, Volume 1, Number 1 / March, 1-27.

Barro, Robert, 2000, "Inequality and Growth in a Panel of Countries," Journal of Economic Growth, 5: 5-28.

Barsky, Robert, and Lutz Killian, 2002, "Do We Really Know that Oil Caused the Great Stagflation?” A Monetary Alternative,” NBER Macroeconomics Annual 2001, vol. 16 edited by Ben Bernanke and Ken Rogoff 137-83 (MIT Press: Cambridge).

Barsky, Robert, and Lawrence Summers, 1988, “Gibson’s paradox and the Gold Standard,” Journal of Political Economy, 96, no. 3, 528-550.

Beny, Laura, and Lisa Cook, 2009, "Metals or Management? Explaining Africa’s Recent Economic Growth Performance,” American Economic Review, 99, no. 2, May, 268-274.

Bhattacharyya, Sambit, and Roland Hodler, 2009, "Natural Resources, Democracy and Corruption,” European Economic Review.

Birdsall, Nancy and Arvind Subramanian, 2004, “Saving Iraq From Its Oil.” Foreign Affairs (July/August): 77-89.

Blattman, Christopher, Jason Hwang, and Jeffrey Williamson, 2007, "Winners and losers in the commodity lottery: The impact of terms of trade growth and volatility in the Periphery 1870-1939," Journal of Development Economics (Elsevier), vol. 82(1), pages 156-179, January. NBER WP 10600.

Bohn, Henning, and Robert Deacon, 2000, “Ownership Risk, Investment, and the Use of Natural Resources,” American Economic Review 90, 526-549.

Brander, James, and M.Scott Taylor, 1997, "International Trade and Open-Access Renewable Resources: The Small Economy,” Canadian Journal of Economics, 30, no. 3, 526-52.

Brunnschweiler, Christa, and Erwin Bulte, 2009, "Natural resources and violent conflict: resource abundance, dependence, and the onset of civil wars," Oxford Economic Papers, October 1; 61(4): 651 - 674.

Bulte, Erwin, Richard Damania, and Robert Deacon, 2005, "Resource Intensity, Institutions and Development,” World Development 33, no. 7, 1029-1044.

Caballero, Ricardo, Emmanuel Farhi, and Pierre-Olivier Gourinchas, 2008, "Financial Crash, Commodity Prices, and Global Imbalances," Brookings Papers on Economic Activity, 2, pp. 1-55. 
Calvo, Guillermo, and Carmen Reinhart, 2002, “Fear of Floating,” Quarterly Journal of Economics, 117, no. 2, May, 379-408.

Caselli, Francesco, 2006, "Power Struggles and the Natural Resource Curse,” LSE Research, London School of Economics.

Chen, Yu-Chin, and Kenneth Rogoff, 2003, "Commodity Currencies,“ Journal of International Economics, Volume 60, Issue 1, May, Pages 133-160

Collier, Paul, 2007, The Bottom Billion: Why the Poorest Countries Are Falling Behind and What Can Be Done About It (Oxford University Press: Oxford).

Collier, Paul, and Benedikt Goderis, 2007, "Commodity Prices, Growth, and the Natural Resource Curse: Reconciling a Conundrum,” Centre for the Study of African Economies Working Paper Series, 274.

Collier, Paul, and Anke Hoeffler, 2004, “Greed and Grievance in Civil War,” Oxford Economic Papers, Vol. 56 (4), pp.563-595.

Collier, Paul, and Anke Hoeffler, 2009, "Testing the Neo-con Agenda: Democracy in Resource-Rich Societies,” European Economic Review 53, 293-308.

Corden, W. Max, 1984, "Booming Sector and Dutch Disease Economics: Survey and Consolidation,” Oxford Economic Papers, (Oxford University Press) 359-380.

Cuddington, John, 1989, “Commodity Export Booms in Developing Countries,” World Bank Research Observer 4, 143-165.

Cuddington, John, 1992, “Long-Run Trends in 26 Primary Commodity Prices,” Journal of Development Economics, 39, 207-27.

Cuddington, John, Rodney Ludema and Shamila Jayasuriya, 2007, "Prebisch-Singer Redux," in Natural Resources: Neither Curse Nor Destiny (Stanford University Press, Palo Alto, and World Bank, Washington DC): 103-140

Cuddington, John, and C. M. Urzua, 1989, "Trends and Cycles in the Net Barter Terms of Trade: A New Approach,” Economic Journal 99: 426-42.

Dasgupta, Partha, and Geoffrey M. Heal, 1985, Economic Theory and Exhaustible Resources (Cambridge University Press: Cambridge UK).

Davis, Graham. 1995. "Learning to Love the Dutch Disease: Evidence from the Mineral Economies,” World Development 23: 1765-79. 
Davis, Jeffrey, Rolando Ossowski, James Daniel, and Steven Barnett, 2001a, “Oil Funds: Problems Posing as Solutions?” Finance and Development 38, no.4 (IMF, Washington DC).

Davis, Jeffrey, Rolando Ossowski, James Daniel, and Steven Barnett, 2001b, "Stabilization and savings funds for nonrenewable resources: Experience and fiscal policy implications,” Occasional Paper 205 (International Monetary Fund: Washington DC). And in Davis, et al, 2003.

Davis, Jeffrey, Rolando Ossowski, and Annalisa Fedelino, editors, 2003, Fiscal Policy Formulation and Implementation in Oil-Producing Countries (IMF: Washington DC).

Deffeyes, Kenneth, 2005, Beyond Oil: The View from Hubbert's Peak (Hill and Wang).

Delacroix, Jacques. 1977. "The Export of Raw Materials and Economic Growth: A Cross-National Study.” American Sociological Review 42: 795-808.

Dunning, Thad, 2008, Crude Democracy: Natural Resource Wealth and Political Regimes (Cambridge University Press: New York).

Easterly, William, and Ross Levine, 2002, “Tropics, Germs, and Endowments,” NBER WP No. 9106; Carnegie-Rochester Conference Series on Public Policy.

Easterly, William, and Ross Levine, 2003, "Tropics, Germans and Crops: How Endowments Influence Economic Development," Journal of Monetary Economics 50, no. 1, 3-39.

Edwards, Sebastian, 1986, “A Commodity Export Boom and the Real Exchange Rate: The Money-Inflation Link," in Neary and van Wijnbergen, eds., Natural Resources and the Macroeconomy (MIT Press: Cambridge).

Eichengreen, Barry, and Ricardo Hausmann, 1999, "Exchange Rates and Financial Fragility,” in New Challenges for Monetary Policy (Kansas City: Federal Reserve Bank of Kansas City), pp. 329-368.

Engerman, Stanley, and Kenneth Sokoloff, 1997, "Factor Endowments, Institutions, and Differential Paths of Growth among New World Economies: A View From Economic Historians of the United States," in How Latin America Fell Behind, edited by Stephen Haber, 260-304, Stanford University Press.

Engerman, Stanley, and Kenneth Sokoloff, 2000, "Institutions, Factor Endowments, and Paths of Development in the New World.” Journal of Economic Perspectives XIV: 217232.

Engerman, Stanley, and Kenneth Sokoloff, 2002, "Factor Endowments, Inequality, and Paths of Development Among New World Economies,” Working Paper 9259, October. 
Englebert, Pierre, 2000, State Legitimacy and Development in Africa (Lynne Rienner Publishers: Boulder).

Fearon, James, and David Laitin, 2003, “Ethnicity, Insurgence and Civil War,” American Political Science Review, 97, no. 2, 75-90.

Findlay, Ronald, and Mats Lundahl, 1994, "Natural Resources "Vent for Surplus" and the Staple Theory," From Classical Economics to Development Economics: Essays in Honor of Hla Myint, edited by Gerald Meier, (St.Martin’s Press: New York).

Findlay, Ronald, and Mats Lundahl, 2001, "Natural Resources and Economic Development: The 1870-1914 Experience,” in Resource Abundance and Economic Development, edited by Richard Auty (World Institute for Development Economics Research).

Frankel, Jeffrey, 1986, "Expectations and Commodity Price Dynamics: The Overshooting Model," American Journal of Agricultural Economics 68, 2, May, 344-48.

Frankel, Jeffrey, 2003a, “A Proposed Monetary Regime for Small Commodity-Exporters: Peg the Export Price ('PEP’),” International Finance, vol. 6, no. 1, Spring, 61-88.

Frankel, Jeffrey, 2003b, "Promoting Better National Institutions: The Role of the IMF," IMF Staff Papers 50, pp. 21-30.

Frankel, Jeffrey, 2005a, "Peg the Export Price Index: A Proposed Monetary Regime for Small Countries,” Journal of Policy Modeling, vol. 27, issue 4, June, pp. 495-508.

Frankel, Jeffrey, 2005b, “On the Tenge: Monetary and Exchange Rate Policy for Kazakhstan,” Short-term Consultancy, Republic of Kazakhstan, April. (Russian translation, Asian Development Bank, 2009.)

Frankel, Jeffrey, 2007, “On the Rand: Determinants of the South African Exchange Rate,” South African Journal of Economics, vol.75, no.3, September, 425-441.

Frankel, Jeffrey, 2008a, “The Effect of Monetary Policy on Real Commodity Prices,” in Asset Prices and Monetary Policy, University of Chicago Press, edited by John Campbell, 291-327.

Frankel, Jeffrey, 2008b, “An Explanation for Soaring Commodity Prices,” Vox, March.

Frankel, Jeffrey, 2009, “A Comparison of Monetary Anchor Options for CommodityExporters in Latin America and the Caribbean," workshop on Myths and Realities of Commodity Dependence: Policy Challenges and Opportunities for Latin America and the Caribbean, World Bank, Sept. 17-18. 
Frankel, Jeffrey, and Gikas Hardouvelis, 1985, "Commodity Prices, Money Surprises, and Fed Credibility," Journal of Money, Credit and Banking 17, 4, Nov., Part I, 427-38.

Frankel, Jeffrey, and Andrew Rose, 2009, "Determination of Agricultural and Mineral Commodity Prices," in Inflation in an Era of Relative Price Shocks (Reserve Bank of Australia).

Gavin, Michael and Roberto Perotti, 1997, "Fiscal Policy in Latin America,” NBER Macroeconomics Annual, Vol. 12, pp. 11-61.

Gavin, Michael, Ricardo Hausmann, Roberto Perotti and Ernesto Talvi, 1996, “Managing Fiscal Policy in Latin America and the Caribbean: Volatility, Procyclicality, and Limited Creditworthiness,” Inter-American Development Bank, RES Working Papers 4032.

Gelb, Alan, 1986, “Adjustment to Windfall Gains: A Comparative Analysis of OilExporting Countries," in "Natural Resources and the Macroeconomy: A Theoretical Framework," in J.Peter Neary and van Sweder Wijnbergen, eds., Natural Resources and the Macroeconomy (MIT Press: Cambridge), 54-93.

Gilbert, Christopher, 1996, “International Commodity Agreements: An Obituary Notice,” World Development, Volume 24, Issue 1, January, Pages 1-19.

Glaeser, Edward, Rafael La Porta, Florencio Lopez-de-Silanes, and Andrei Shleifer, 2004, “Do Institutions Cause Growth?” Journal of Economic Growth 9, no. 3, 271-303.

Gregory, R.G., 1976, "Some Aspects of Growth in the Mineral Sector,” Australian Journal of Agricultural Economics, 20, 71-91.

Grilli, Enzo, and Maw Cheng Yang, 1988, "Primary Commodity Prices, Manufactured Goods Prices, and the Terms of Trade of Developing Countries: What the Long Run Shows,” World Bank Economic Review 2, no. 1, 1-47.

Gylfason, Thorvaldur, 2000, "Resources, Agriculture and Economic Growth in Economies in Transition,” Kyklos 53, Issue 4, pp.545-79.

Gylfason, Thorvaldur, 2001, "Natural Resources, Education, and Economic Development,” European Economic Review 45, no. 4-6, 847-59.

Gylfason, Thorvaldur, Tryggvi Thor Herbertsson, and Gylfi Zoega, 1999, “A Mixed Blessing,” Macroeconomic Dynamics, 3: 204-225 (Cambridge University Press).

Gylfason, Thorvaldur, and Gylfi Zoega, 2002, “Inequality and Economic Growth: Do Natural Resources Matter?” CESinfo working paper number 712, April. 
Gylfason, Thorvaldur, and Gylfi Zoega, 2006, "Natural Resources and Economic Growth: The Role of Investment,” The World Economy Vol. 29, No. 8, August, pp. 10911115.

Haber, Stephen, and Victor Menaldo, 2009, “Do Natural Resources Fuel Authoritarianism? A Reappraisal of the Resource Curse” May. Presented at workshop on Myths and Realities of Commodity Dependence: Policy Challenges and Opportunities for Latin America and the Caribbean, World Bank, Sept. 17-18, 2009.

Hadass, Yael, and Jeffrey Williamson, 2003, “Terms of Trade Shocks and Economic Performance 1870-1940: Prebisch and Singer Revisited,” Economic Development and Cultural Change (University of Chicago Press), vol. 51(3), pages 629-56, April. NBER WP 8188, 2001.

Hall, Robert, and Chad Jones, 1999, "Why Do Some Countries Produce So Much More Output per Worker than Others?” Quarterly Journal. of Economics 114, 1, Feb., 83-116.

Hartwick, John, 1977, "Intergenerational Equity and the Investing of Rents from Exhaustible Resources,” American Economic Review, Vol. 67, No. 5, Dec., pp. 972-974

Harvey, David, Neil Kellard, Jakob Madsen, and Mark Wohar, 2010, "The PrebischSinger Hypothesis: Four Centuries of Evidence,” Review of Economics and Statistics, 92, no. 2, May, 367-377.

Hausmann, Ricardo, Bailey Klinger and Jose Lopez-Calix, 2009, “Export Diversification in Algeria,” World Bank, MNSED, April.

Hausmann, Ricardo, Bailey Klinger and Robert Lawrence, 2008, "Examining Beneficiation,” CID Working Paper No. 162, Harvard University, May.

Hausmann, Ricardo, and Roberto Rigobon, 2003, “An Alternative Interpretation of the 'Resource Curse': theory and Policy Implications,” in Fiscal Policy Formulation and Implementation in Oil-Producing Countries, edited by Jeffrey Davis (International Monetary Fund: Washington, DC), p 12-44.

Helliwell, John, 1994, "Empirical Linkages Between Democracy and Economic Growth, "British Journal of Political Science 24, 225-248.

Helm, Dieter, “Credibility, Commitment and Regulation,” In The Natural Resources Trap, edited by Bill Hogan and Federico Sturzenegger, forthcoming (MIT Press: Cambridge MA) 2010.

Herb, Michael, 2005, “No Representation without Taxation? Rents, Development and Democracy,” Comparative Politics 37, no. 3, 297-317.

Hodler, Roland, 2006, “The Curse of Natural Resources in Fractionalized Countries,” European Economic Review 50, no. 6, 1367-86. 
Holmøy, Erling, 2010, “Mineral Rents and Social Policy: The Case of the Norwegian Government Oil Fund,” in Katja Hujo and Shea McClanahan , editors, Financing Social Policy: Mobilizing Resources for Social Development (UNRISD/Palgrave MacMillan: London), January.

Hotelling, Harold, 1931, “The Economics of Exhaustible Resources,” Journal of Political Economy, 39, no. 2, 137-75.

Hubbert, Marion King, 1956, "Nuclear Energy and the Fossil Fuels" (presented at The Spring Meeting of the Southern District, Division of Production, American Petroleum Institute, San Antonio, Texas, March 7-9). Publication No. 95 of Shell Development Company, Exploration and Production Research Division, Houston Texas, June 1956. Available online at: http://www.hubbertpeak.com/hubbert/1956/1956.pdf.

Huber, Evelyne, Dietrich Rueschemeyer, and John Stephens, 1993, "The Impact of Economic Development on Democracy." Journal of Economic Perspectives 7, 71-85.

Humphreys, Macartan, 2005, "Natural Resources, Conflicts, and Conflict Resolution: Uncovering the Mechanisms,” Journal of Conflict Resolution 49, 508-37.

Humphreys, Macartan, Jeffrey Sachs, and Joseph Stiglitz, 2007, Escaping the Resource Curse (Columbia University Press: New York).

Humphreys, Macartan, Jeffrey Sachs, and Joseph Stiglitz, 2007, "Future Directions for the Management of Natural Resources,” Chapter 12 in Humphreys, Sachs, and Stiglitz, eds., 2007, Escaping the Resource Curse (Columbia University Press: New York), 322336.

Humphreys, Macartan, and Martin Sandhu, 2007, “The Political Economy of Natural Resource Funds” in Humphreys, Macartan, Jeffrey Sachs, and Joseph Stiglitz, eds., Escaping the Resource Curse (Columbia University Press: New York).

Huntington, Samuel, 1991, The Third Wave: Democratization in the Late Twentieth Century (University of Oklahoma Press: Norman, Oklahoma).

Iimi, Atsushi, 2006, “Did Botswana Escape from the Resource Curse?” IMF Working Paper No. 06/138, June.

Ilzetski, Ethan, and Carlos Vegh, 2008, "Procyclical Fiscal Policy in Developing Countries: Truth or Fiction?” NBER WP no. 14191.

International Monetary Fund, 2005, Chile 2005 Article IV Consultation, IMF country Report 05/013, September.

Isham, Jonathan, Michael Woolcock, Lant Pritchett, and Gwen Busby, 2005, “The Varieties of Resource Experience: Natural Resource Export Structures and the Political 
Economy of Economic Growth,” The World Bank Economic Review (Oxford University Press on behalf of the International Bank for Reconstruction and Development).

Jensen, Nathan, and Leonard Wantchekon, 2004, "Resource Wealth and Political Regimes in Africa,” Comparative Political Studies 37, 816-41.

Kaldor, M., Karl, T.L. and Y. Said, 2007, Oil Wars (Pluto Press), edited by M. Kaldor, T.L. Karl and Y. Said.

Kaminsky, Graciela, Carmen Reinhart, and Carlos Vegh, 2005, "When It Rains, It Pours: Procyclical Capital Flows and Macroeconomic Policies," NBER Macroeconomics Annual 2004, Vol. 19, pages 11-82.

Karl, Terry Lynn, 1997, The Paradox of Plenty: Oil Booms and Petro-States (University of California Press: Berkeley CA).

Kaufmann, D., A. Kraay and P. Zoido-Lobaton, 2002, “Governance Matters II -- Updated Indicators for 2000/01,” World Bank Research Dept. WP No. 2772.

Kellard, Neil, and Mark Wohar, 2006, "On the prevalence of trends in primary commodity prices ,” Journal of Development Economics, 79, no.1, February, 146-167 .

Killian, Lutz, 2009, "Not All Price Shocks Are Alike: Disentangling Demand and Supply Shocks in the Crude Oil Market," American Economic Review 99, no. 3, 1053-1069

Krautkraemer, Jeffrey, 1998, “Nonrenewable Resource Scarcity,” Journal of Economic Literature 36, December, 2065-2107.

Kremers, Jeroen, 1986, "The Dutch Disease in the Netherlands,” in Neary and van Wijnbergen, eds., Natural Resources and the Macroeconomy (MIT Press: Cambridge), 96-136.

Lederman, Daniel, and William Maloney, 2008, "In Search of the Missing Resource Curse," Economia 9, no. 1, Fall.

Leite, Carlos and Jens Weidman, 1999, “Does Mother Nature Corrupt?” IMF Working Paper 99/85, July.

Libecap, Gary, 1978, "Economic Variables and the Development of the Law: The Case of Western Mineral Rights," Journal of Economic History, June, Vol. 38, No. 2, pp. 338362. Reprinted in Lee Alston, Thrainn Eggertsson, and Douglass North, eds., Empirical Studies in Institutional Change (Cambridge University Press), 1996.

Libecap, Gary, 1989, Contracting for Property Rights (Cambridge University Press: Cambridge UK). 
Lipset, Seymour Martin, 1994, "The Social Requisites of Democracy Revisited." American Sociological Review 59, 1-22.

Luciani, Giacomo, 1997, Allocation versus Production States: A Theoretical Framework,” in Hazem Beblawi and Giacomo Luciani, eds., The Rentier State (Croom Helm: New York).

Luong, Pauline Jones, and Erika Weinthal, 2010, Oil Is Not a Curse: Ownership Structure and Institutions in Soviet Successor States (Cambridge University Press: Cambridge UK).

Mahdavy, Hussein, 1970, "The Patterns and Problems of Economic Development in Rentier States: The Case of Iran,” in M.A. Cook, editor, Studies in the Economic History of the Middle East (Oxford University Press: London).

Malthus, Thomas, 1798, An essay on the principle of population (J.Johnson: London).

Manzano, Osmel, and Roberto Rigobon, 2008, "Resource Curse or Debt Overhang,” Economia 9, no. 1, Fall. NBER WP 8390.

Matsuyama, Kiminori, 1992, "Agricultural Productivity, Comparative Advantage, and Economic Growth," Journal of Economic Theory 58, December, 317-334.

McSherry, Brendan, 2006, "The Political Economy of Oil in Equatorial Guinea,” African Studies Quarterly 8, 23-45.

Medas, Paolo, and Daria Zakharova, 2009, "Primer on Fiscal Analysis in Oil-Producing Countries,” IMF working paper 56, March.

Mehlum, Halvor, Karl Moene, and Ragnar Torvik, 2006, "Institutions and the Resource Curse,” Economic Journal 116, 508, 1-20.

Mendoza, Enrique G. and P. Marcelo Oviedo, "Fiscal Policy and Macroeconomic Uncertainty in Developing Countries: The Tale of the Tormented Insurer," NBER Working Paper No. 12586, October 2006.

Mendoza, Enrique, and Marco Terrones, "An Anatomy of Credit Booms: Evidence from Macro Aggregates and Micro Data,” NBER Working Paper No. 14049, May 2008.

Mikesell, Raymond, 1997, "Explaining the Resource Curse, with Special Reference to Mineral-Exporting Countries,” Resources Policy Vol.23, Issue 4, December, pp: 191-199.

Minier, Jenny A., 1998, “Democracy and Growth: Alternative Approaches,” Journal of Economic Growth 3, 241-266.

Nankani, Gobind T., 1979, Development Problems of Mineral Exporting Countries. (World Bank, Washington, DC). 
Neary, J. Peter, and Sweder van Wijnbergen, 1986, "Natural Resources and the Macroeconomy: A Theoretical Framework,” in Neary and van Wijnbergen, eds., Natural Resources and the Macroeconomy, (MIT Press: Cambridge, 1986), 13- 45.

Noland, Marcus, 2008, “Explaining Middle Eastern Political Authoritarianism I: The Level of Democracy,” Review of Middle East Economics and Finance 4, no. 1.

Norman, Catherine, 2009, "Rule of Law and the Resource Curse: Abundance Versus Intensity,” Environmental Resource Economics 43:2 (June), 183-207.

North, Douglass, 1994, "Economic Performance Through Time," American Economic Review, 84, no. 3, June, 359-368.

Okruhlik, Gwenn, 1999, "Rentier Wealth, Unruly Law and the Rise of Opposition: The Political Economy of Oil States,” Comparative Politics 31, 3: 295-315.

Pindyk, Robert, 1979, “The Cartelization of World Commodity Markets ,” The American Economic Review, Vol. 69, No. 2, Papers and Proceedings, May, pp. 154-158

Pindyck, Robert, 1999, “The Long-Run Evolution of Energy Prices,” The Energy Journal; 1999; 20, 2

Pindyck, Robert, and Julio Rotemberg, 1990, “The Excess Co-Movement of Commodity Prices,” The Economic Journal, Vol. 100, No. 403, Dec., pp. 1173-1189

Poelhekke, Steven, and, Frederick van der Ploeg, 2007, Volatility, Financial Development and the Natural Resource Curse,” CEPR DP6513, October.

Prebisch, Raul, 1950, The Economic Development of Latin America and Its Principal Problems (New York).

Reinhart, Carmen, and Peter Wickham, 1994, "Commodity Prices: Cyclical Weakness or Secular Decline?” IMF Staff Papers 41, June.

Reinhart, Carmen, and Vincent Reinhart, 2009, "Capital Flow Bonanzas: An Encompassing View of the Past and Present," in J.Frankel and C.Pissarides, eds., NBER International Seminar in Macroeconomics 2008, University of Chicago Press.

Robinson, James, Ragnar Torvik, and Thierry Verdier, 2006, "Political Foundations of the Resource Curse,” Journal of Development Economics 79, no. 2, 446-68.

Rodriguez, Francisco, and Jeffrey Sachs, 1999, "Why Do Resource-Abundant Economies Grow More Slowly?” Journal of Economic Growth 4, no. 3, 277-303.

Rodrik, Dani, Arvind Subramanian, and Francesco Trebbi, 2003, "Institutions Rule: The Primacy of Institutions over Geography and Integration in Economic Development,” Journal of Economic Growth 9, no. 2, 131-165. CID Working Paper No. 97, 2002. 
Røed Larsen, Erling, 2004, Escaping the Resource Curse and the Dutch Disease? When and Why Norway Caught up with and Forged ahead of Its Neighbors," Discussion Papers No. 377, May, Statistics Norway, Research Department.

Ross, Michael, 1999, “The Political Economy of the Resource Curse,” World Politics 51, 297-322.

Ross, Michael, 2001, “Does Oil Hinder Democracy?” World Politics 53, no.3, 325-61.

Ross, Michael, 2006, “A Closer Look at Oil, Diamonds, and Civil War,” Annual Review of Political Science 9, 265-300.

Ross, Michael, 2007, “How Mineral-Rich States Can Reduce Inequality,” Chapter 9 in Escaping the Resource Curse, edited by M.Humphreys, J.Sachs and J.Stiglitz (Columbia University Press: NY), pp.236-255.

Rosser, Andrew, 2007, “Escaping the Resource Curse: The Case of Indonesia.” Journal of Contemporary Asia, Vol. 37, No. 1, pp. 38-58.

Sachs, Jeffrey, 2007, "How to Handle the Macroeconomics of Oil Wealth,” Ch. 7 in Escaping the Resource Curse, edited by M.Humphreys, J.Sachs and J.Stiglitz (Columbia University Press: NY), pp.173-193.

Sachs, Jeffrey, and Andrew Warner, 1995, "Natural Resource Abundance and Economic Growth,” in G. Meier and J. Rauch, eds., Leading Issues in Economic Development, New York: Oxford University Press. NBER WP 5398.

Sachs, Jeffrey, and Andrew Warner, 2001, “The Curse of Natural Resources,” European Economic Review (Elsevier), vol. 45(4-6), pages 827-838, May.

Sala-I-Martin, Xavier, and Arvind Subramanian, 2003, “Addressing the Natural Resource Curse: An Illustration from Nigeria.” IMF Working Paper WP/03/139.

Sarraf, Maria, and Moortaza Jiwanji, October 2001, "Beating the Resource Curse: The Case of Botswana.” Environmental Economics Series Paper No. 83.

Shaw, Timothy M., 1984, "The State of Nigeria: Oil Crises, Power Bases and Foreign Policy” Canadian Journal of African Studies 18, 2: 393-405.

Singer, Hans W, 1950, "US Foreign Investment in Underdeveloped Areas: The Distribution of Gains between Investing and Borrowing Countries," American Economic Review, Papers and Proceedings, 40, May: 473-485.

Sinnott, Emily, 2009, “Commodity Prices and Fiscal Policy in Latin America and the Caribbean,” presented at workshop on Myths and Realities of Commodity Dependence: 
Policy Challenges and Opportunities for Latin America and the Caribbean, World Bank, Sept. 17-18, 2009.

Skocpol, Theda, 1982, “Rentier State and Shi'a Islam in the Iranian Revolution” Theory and Society 11, 3: 265-283.

Smith, Benjamin, 2004, "Oil Wealth and Regime Survival in the Developing World, 1960-1999,” American Journal of Political Science 48(2), 232-246. .

Smith, Benjamin, 2007, Hard Times in the Land of Plenty: Oil Politics in Iran and Indonesia (Cornell University Press: Ithaca NY).

Solow, Robert, 1986, "On the Intergenerational Allocation of Natural Resources," The Scandinavian Journal of Economics, Vol. 88, No. 1, pp. 141-149

Stevens, Paul, 2003, “Resource Impact: Curse or Blessing? A Literature Survey,” Journal of Energy Literature 9, no.1, 1-42.

Talvi, Ernesto, and Carlos Vegh, 2005, "Tax Base Variability and Procyclicality of Fiscal Policy,” Journal of Development Economics 78, no. 1, 156-190.

Tavares, José, and Romain Wacziarg, 2001, “How Democracy Affects Growth,” European Economic Review, Volume 45, Issue 8, Pages 1341-1378.

Tornell, Aaron, and Philip Lane, 1999, “The Voracity Effect,” American Economic Review 89, no. 1, March: 22-46.

Torvik, Ragnar, 2001, "Learning by Doing and the Dutch Disease," European Economic Review (Elsevier) 45, 285-306.

Ulfelder, Jamy, 2007, "Natural Resource Wealth and the Survival of Autocracies," Comparative Political Studies 40, 8, 995-1018.

Vandewalle, Dirk, 1998, Libya since Independence: Oil and State-Building (Cornell University Press: Ithaca NY).

Wantchekon, Leonard 2002, "Why do Resource Dependent Countries Have Authoritarian Governments?” Journal of African Finance and Economic Development 2, 57-77.

Wright, Gavin, and Jesse Czelusta, 2003, "Mineral Resources and Economic Development,” Conference on Sector Reform in Latin America, Stanford Center for International Development Nov. 13-15.

Wright, Gavin, and Jesse Czelusta, 2004, “The Myth of the Resource Curse,” Challenge 47 (March-April). 
Wright, Gavin, and Jesse Czelusta, 2006, “Resource-Based Growth Past and Present,” in Daniel Lederman and William Maloney, editors, Neither Curse nor Destiny: Natural Resources and Development (Stanford University Press and World Bank Publication).

Zakaria, Fareed, 1997, “The Rise of Illiberal Democracy,” Foreign Affairs, November.

Zakaria, Fareed, 2004, The Future of Freedom: Illiberal Democracy at Home and Abroad (Norton: NY). 